\title{
Emerging infectious disease threats to European herpetofauna
}

\author{
Steven J. R. Allain ${ }^{1} \&$ Amanda L. J. Duffus ${ }^{2}$ \\ Durrell Institute of Conservation and Ecology, University of Kent, Canterbury, Kent, UK \\ 2 Department of Natural Sciences, School of Nursing, Health, and Natural Sciences, Gordon State College, Barnesville, Georgia, USA
}

In the past decade, infectious disease threats to European herpetofauna have become better understood. Since the 1990s, three major emerging infections in amphibians have been identified (Batrachochytrium dendrobatidis, B. salamandrivorans, and ranaviruses) as well as at least one of unknown status (herpesviruses), while two major emerging infections of reptiles (Ophidiomyces ophiodiicola and ranaviruses) have been identified in wild European populations. The effects of emerging infections on populations have ranged from non-existent to local extirpation. In this article, we review these major infectious disease threats to European herpetofauna, including descriptions of key mortality and/or morbidity events in Europe of their emergence, and address both the distribution and the host diversity of the agent. Additionally, we direct the reader to newly developed resources that facilitate the study of infectious agents in herpetofauna and again stress the importance of an interdisciplinary approach to examining these infectious diseases.

Keywords: Batrachochytrium dendrobatids, B. salamandrivorans, herpesviruses, ophidiomycosis, ranaviruses, amphibians, reptiles

\section{INTRODUCTION}

V ertebrates are currently experiencing an ongoing mass extinction event (Ceballos et al., 2017). Infectious diseases are contributing to these declines as they are able to cause major population declines, and can contribute to both local and global extirpations (de Castro \& Bolker, 2005). Emerging infections have long been known to pose a serious threat to biodiversity (Scott, 1988; Daszak et al., 2000). The link between the decline and extinction of many amphibian populations with the emergence of infectious agents was drawn approximately 20 years ago (Berger et al., 1998; Daszak et al., 1999). While the link between declines in some reptile populations and emerging infections have been less clear, in the past decade growing evidence shows emerging infectious diseases (e.g. snake fungal disease, Lorch et al., 2016) that are clearly able to decimate populations of these animals as well. Infectious disease related declines can even occur in large, seemingly robust populations of wildlife (Daszak et al., 2003). Therefore, the effects in smaller, more fragile, populations are likely to be even more extreme. Unfortunately, populations of both amphibians and reptiles are shrinking around the globe (Gibbons et al., 2000; Sodhi et al., 2008; Stuart et al., 2004; Todd et al., 2010). This will be exacerbated by other factors such as anthropogenic environmental stressors and infectious disease, which negatively affect wildlife health (Acevedo-Whitehouse \& Duffus, 2009).
Duffus and Cunningham (2010) reviewed two major disease threats to European amphibians, Batrachochytrium dendrobatidis $(B d)$ and ranaviruses. Since the publication of that review, other emerging infectious diseases in European amphibian populations have been identified, $B$. salamandrivorans ( $B s a l$, Martel et al., 2013), and the potentially emerging amphibian herpesviruses (Franklinos et al., 2018; Origgi et al., 2017). In reptiles, the emergence of two troubling infectious diseases has also been documented in wild populations, snake fungal disease (Ophidiomyces ophiodiicola, Franklinos et al., 2017) and ranaviruses (Alves de Matos et al., 2011).

\section{EMERGING INFECTIOUS DISEASE THREATS TO AMPHIBIANS}

BATRACHOCHYTRIUM DENDROBATIDIS

The amphibian chytrid fungus (Batrachochytrium dendrobatidis, hereafter $B d$ ) is a non-hyphal zoosporic chytridiomycete fungus implicated in the decline of amphibian species globally (Skerratt et al., 2007). Batrachochytrium dendrobatidis is the causative agent of amphibian chytridiomycosis (Berger et al., 1998) that was first linked to declines in amphibian communities in Central America and Australia. Since then, $B d$ has been found all over the globe and has been associated with the extinction of at least 90 amphibian species, and the declines of several hundred others (Wake \& Vredenburg, 2008; Scheele et al., 2019). Bd is considered 
to be a pandemic pathogen in amphibians (Pasmans et al., 2006) with low genetic diversity among different isolates indicating a rapid spread of the pathogen. Of these strains, the global panzootic lineage (BdGPL) has been attributed to most amphibian declines having likely emerged as a hybrid between less virulent strains (Farrer et al., 2011). For a long time, there was speculation as to where $B d$ had originated, with evidence of America or Africa (Weldon et al., 2004), but recent research shows that the infection originated in east Asia ( $\mathrm{O}^{\prime}$ Hanlon et al., 2018).

The standard detection method for $B d$ is to swab an individual with a sterile swab and then test for the presence of $B d$ DNA using real-time PCR (also known as qPCR) after processing the sample (Boyle et al., 2004). Gross clinical signs of $B d$ infection in adult amphibians include, but are not limited to: anorexia, lethargy, unusual skin shedding, reddening of the skin (especially in the vent and upper thigh regions), convulsions and loss of the righting reflex (Fig. 1; Nichols et al., 2011). However, the clinical signs of $B d$ vary among species, their life history stages, and other factors such as environmental conditions. In larval stages, clinical signs of chytridiomycosis are also variable. They include but are not limited to: depigmentation of mouthparts, swimming difficulties, and lethargy (reviewed in van Rooij et al., 2015). Therefore, to properly diagnose chytridiomycosis, histology should be used alongside the standard method of qPCR. The pathogen only infects the keratinized tissues of the body, such as the skin in metamorphosed animals and the mouthparts in larvae (Daszak et al., 1999; Marantelli et al., 2004). There are limited studies on the effects $B d$ has on life history, but Garner et al. (2009a) were able to show that experimental infection decreased the time it took tadpoles (of the common toad, Bufo bufo) to reach metamorphosis, but also decreased their weight. At higher doses, there were also higher levels of mortality, but these surprising results show that there may be advantageous effects when tadpoles are infected with $B d$. For more information on host-fungal interactions of $B d$, please see Van Rooij et al. (2015), and for further

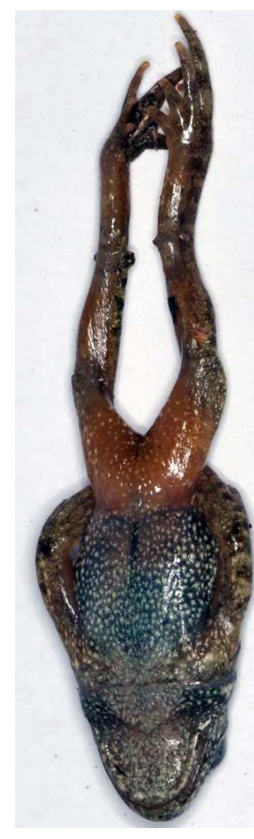
details on the immune response of amphibians to $B d$, please refer to Grogan et al. (2018).

Currently the potential impacts of $B d$ on European amphibian communities are not fully understood, but within the past decade multiple studies have started to help illuminate the scientific community (e.g. Bielby et al., 2015; Rosa et al., 2013; Tobler \& Schmidt, 2010). The amphibian chytrid fungus has both a wide

Figure 1. A common midwife toad (A. obstetricians) that died because of $B d$ caused chytridiomycosis. Note the strange position of the legs, due to muscle spasms and the reddish hue of the vent and thighs. Photo by Frank Pasmans.

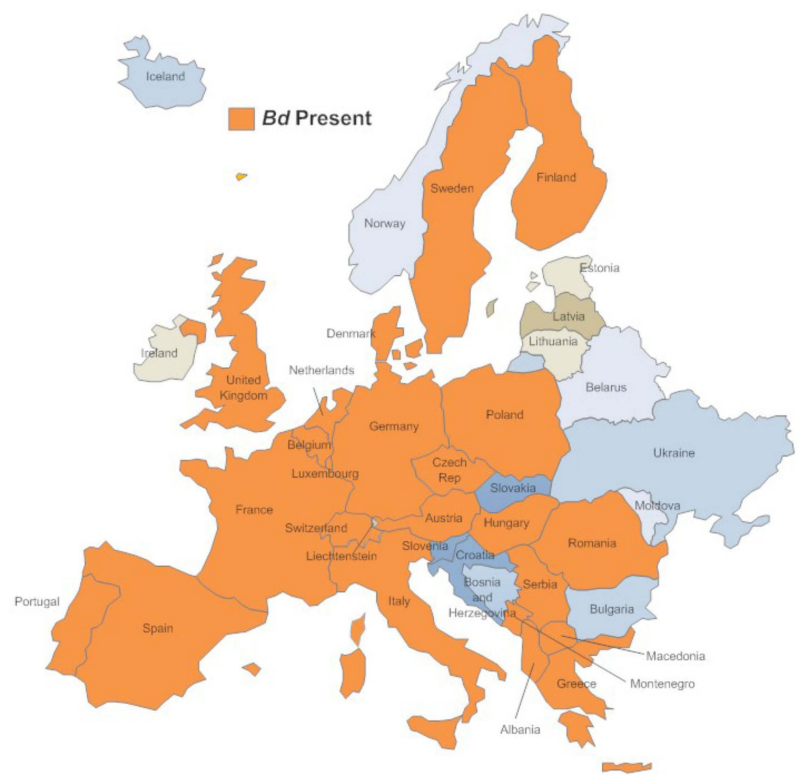

Figure 2. The distribution of Batrachochytrium dendrobatidis $(B d)$ in wild European amphibian populations.

geographic range and a wide host range within Europe (Table 1 and Fig. 2), with infection first being identified in wild populations in 2001 (Bosch et al., 2001). So far, the susceptibility of species across Europe is not fully understood, but $B d$ has been attributed to declines seen in species including the common midwife toad (Alytes obstetricans), common toad (B. bufo) and European fire salamander (Salamandra salamandra) across the Iberian Peninsula (Bosch et al., 2001; Bosch \& Martínez-Solano, 2006). Elsewhere in Europe, infection does not always lead to the development of disease, which may be why we have not seen the mass-die offs of amphibians such as those elsewhere in the world (Berger et al., 1998). Experimentally, some anurans species have been shown to have a limited immunity to $B d$, whilst others have exhibited tolerance, such as the water frogs (Pelophylax spp.), which may be an important factor for host-disease dynamics (Daum et al., 2012; Woodhams et al., 2012).

The apparent lack of mass die-offs within many areas Europe may be attributed to the fact that $B d$ has multiple strains of varying virulence (Fisher et al., 2009). Research in the Netherlands has shown over a seven-year time period, populations of the yellow-bellied toad (Bombina variegata) are able to coexist with $B d$ (Spitzen-van der Sluijs et al., 2017). Although for now the toads seem to be safe, this may change in the future due to the effects of climate change and other such environmental effects. For more information on the environmental impact of hostpathogen interactions, which can be hugely deterministic in some cases, see Blaustein et al. (2018) for an in-depth discussion. Experiments have also shown that some salamanders such as those in the genus Speleomantes also have some immunity to $B d$ (Pasmans et al., 2013). This combined effect of peptide defence and varying $B d$ strains show that at least for now, some species of European amphibians are protected against the potentially negative effects of $B d$ outbreaks (Fisher et al., 2009).

BATRACHOCHYTRIUM SALAMANDRIVORANS 
Table 1. Summary of the countries and amphibian species affected by Batrachochytrium dendrobatidis infections in wild European populations.

\begin{tabular}{|c|c|c|c|}
\hline Location & Common Name & Species & First Report \\
\hline Albania & $\begin{array}{l}\text { Macedonian crested newt } \\
\text { Yellow-bellied toad }\end{array}$ & $\begin{array}{l}\text { Triturus macedonicus } \\
\text { Bombina variegata }\end{array}$ & $\begin{array}{l}\text { Vojar et al., } 2017 \\
\text { Vojar et al., } 2017\end{array}$ \\
\hline Austria & $\begin{array}{l}\text { Alpine newt } \\
\text { Smooth newt } \\
\text { European water frog complex } \\
\text { Fire-bellied toad } \\
\text { Great crested newt } \\
\text { Italian crested newt } \\
\text { Yellow-bellied toad }\end{array}$ & $\begin{array}{l}\text { Ichthyosaura alpestris } \\
\text { Lissotriton vulgaris } \\
\text { Pelophylax spp. } \\
\text { B. bombina } \\
\text { T. cristatus } \\
\text { T. carnifex } \\
\text { B. variegata }\end{array}$ & $\begin{array}{l}\text { Sztatecsny \& Glaser, } 2011 \\
\text { Sztatecsny \& Glaser, } 2011 \\
\text { Sztatecsny \& Glaser, } 2011 \\
\text { Sztatecsny \& Glaser, } 2011 \\
\text { Sztatecsny \& Glaser, } 2011 \\
\text { Sztatecsny \& Glaser, } 2011 \\
\text { Sztatecsny \& Glaser, } 2011\end{array}$ \\
\hline Belgium & $\begin{array}{l}\text { African clawed frog } \\
\text { American bullfrog } \\
\text { Common midwife toad } \\
\text { Common toad } \\
\text { Marbled newt }\end{array}$ & $\begin{array}{l}\text { Xenopus laevis } \\
\text { Lithobates catesbeianus } \\
\text { Alytes obstetricans } \\
\text { Bufo bufo } \\
\text { T. marmoratus }\end{array}$ & $\begin{array}{l}\text { Spitzen-van der Sluijs et al., } 2014 \\
\text { Spitzen-van der Sluijs et al., } 2014 \\
\text { Pasmans et al., } 2010 \\
\text { Martel et al., } 2012 \\
\text { Spitzen-van der Sluijs et al., } 2014\end{array}$ \\
\hline Czech Republic & $\begin{array}{l}\text { Alpine newt } \\
\text { Eurasian toads } \\
\text { European water frog complex } \\
\text { Fire-bellied toad } \\
\text { Great crested newt } \\
\text { Yellow-bellied toad }\end{array}$ & $\begin{array}{l}\text { Ichthyosaura alpestris } \\
\text { Bufo sp. } \\
\text { Pelophylax spp. } \\
\text { B. bombina } \\
\text { T. cristatus } \\
\text { B. variegata }\end{array}$ & $\begin{array}{l}\text { Civiš et al., } 2012 \\
\text { Baláž et al., } 2014 \\
\text { Baláž et al., } 2014 \\
\text { Civiš et al., } 2012 \\
\text { Civiš et al., } 2012 \\
\text { Civiš et al., } 2012\end{array}$ \\
\hline Denmark & $\begin{array}{l}\text { Common frog } \\
\text { Edible frog }\end{array}$ & $\begin{array}{l}\text { Rana temporaria } \\
\text { P. esculentus }\end{array}$ & $\begin{array}{l}\text { Scalera et al., } 2008 \\
\text { Scalera et al., } 2008\end{array}$ \\
\hline Finland & Common frog & R. temporaria & Patrelle et al., 2012 \\
\hline France & $\begin{array}{l}\text { American bullfrog } \\
\text { Common midwife toad } \\
\text { European water frog complex }\end{array}$ & $\begin{array}{l}\text { L. catesbeianus } \\
\text { A. obstetricans } \\
\text { Pelophylax spp. }\end{array}$ & $\begin{array}{l}\text { Garner et al., } 2006 \\
\text { Garner et al., } 2005 \\
\text { Ouellet et al., } 2012\end{array}$ \\
\hline Germany & $\begin{array}{l}\text { Agile frog } \\
\text { Alpine newt } \\
\text { Common frog } \\
\text { Common midwife toad } \\
\text { Smooth newt } \\
\text { Common toad } \\
\text { European water frog complex } \\
\text { European spadefoot toad } \\
\text { European tree frog } \\
\text { Fire-bellied toad } \\
\text { Fire salamander } \\
\text { Great crested newt } \\
\text { Green toad } \\
\text { Moor frog } \\
\text { Natterjack toad } \\
\text { Palmate newt } \\
\text { Yellow-bellied toad }\end{array}$ & $\begin{array}{l}\text { R. dalmatina } \\
\text { I. alpestris } \\
\text { R. temporaria } \\
\text { A. obstetricans } \\
\text { L. vulgaris } \\
\text { B. bufo } \\
\text { Pelophylax spp. } \\
\text { Pelobates fuscus } \\
\text { Hyla arborea } \\
\text { B. bombina } \\
\text { Salamandra salamandra } \\
\text { T. cristatus } \\
\text { Bufotes viridis } \\
\text { R. arvalis } \\
\text { Epidalea calamita } \\
\text { L. helveticus } \\
\text { B. variegata }\end{array}$ & $\begin{array}{l}\text { Ohst et al., } 2011 \\
\text { Ohst et al., } 2011 \\
\text { Ohst et al., } 2011 \\
\text { Ohst et al., } 2011 \\
\text { Ohst et al., } 2011 \\
\text { Ohst et al., } 2011 \\
\text { Ohst et al., } 2011 \\
\text { Ohst et al., } 2011 \\
\text { Ohst et al., } 2011 \\
\text { Ohst et al., } 2011 \\
\text { Ohst et al., } 2011 \\
\text { Ohst et al., } 2011 \\
\text { Ohst et al., } 2013 \\
\text { Ohst et al., } 2011 \\
\text { Ohst et al., } 2011 \\
\text { Ohst et al., } 2011 \\
\text { Ohst et al., } 2011\end{array}$ \\
\hline Greece & $\begin{array}{l}\text { Epirus water frog } \\
\text { Green frog } \\
\text { Marsh frog }\end{array}$ & $\begin{array}{l}\text { P. epeiroticus } \\
\text { B. viridis } \\
\text { P. ridibundus }\end{array}$ & $\begin{array}{l}\text { Azmanis et al., } 2016 \\
\text { Azmanis et al., } 2016 \\
\text { Azmanis et al., } 2016\end{array}$ \\
\hline Hungary & $\begin{array}{l}\text { Alpine newt } \\
\text { Edible frog } \\
\text { European water frog complex } \\
\text { Fire-bellied toad } \\
\text { Green toad } \\
\text { Marsh frog } \\
\text { Yellow-bellied toad }\end{array}$ & $\begin{array}{l}\text { I. alpestris } \\
\text { P. esculentus } \\
\text { Pelophylax spp. } \\
\text { B. bombina } \\
\text { B. viridis } \\
\text { P. ridibundus } \\
\text { B. variegata }\end{array}$ & $\begin{array}{l}\text { Vörös et al., } 2018 \\
\text { Vörös et al., } 2018 \\
\text { Tünde et al., } 2012 \\
\text { Vörös et al., } 2018 \\
\text { Vörös et al., } 2018 \\
\text { Vörös et al., } 2018 \\
\text { Tünde et al., } 2012\end{array}$ \\
\hline Italy & $\begin{array}{l}\text { American bullfrog } \\
\text { Apennine toad } \\
\text { Edible frog } \\
\text { Edible frog complex } \\
\text { Fire-bellied toad } \\
\text { Italian agile frog } \\
\text { Italian alpine newt } \\
\text { Italian crested newt } \\
\text { Italian fire salamander } \\
\text { Italian stream frog } \\
\text { Sardinian brook salamander } \\
\text { Tyrrhenian painted frog }\end{array}$ & $\begin{array}{l}\text { Lithobates catesbeianus } \\
\text { B. pachypus } \\
\text { P. esculentus } \\
\text { Pelophylax spp. } \\
\text { B. variegata } \\
\text { R. latastei } \\
\text { I. alpestris apuanus } \\
\text { T. carnifex } \\
\text { S. salamandra gigliolii } \\
\text { R. italica } \\
\text { Euproctus platycephalus } \\
\text { Discoglossus sardus }\end{array}$ & $\begin{array}{l}\text { Garner et al., } 2006 \\
\text { Stagni et al., } 2004 \\
\text { Adams et al., } 2008 \\
\text { Simoncelli et al., } 2005 \\
\text { Stagni et al., } 2002 \text { (in Bovero et al., 2008) } \\
\text { Garner et al., } 2004 \text { (in Bovero et al., 2008) } \\
\text { Zampiglia et al., } 2013 \\
\text { Grasseli et al., } 2019 \\
\text { Zampiglia et al., } 2013 \\
\text { Zampiglia et al., } 2013 \\
\text { Bovero et al., } 2008 \\
\text { Bielby et al., } 2009\end{array}$ \\
\hline Luxembourg & $\begin{array}{l}\text { Alpine newt } \\
\text { Edible frog complex } \\
\text { Palmate newt }\end{array}$ & $\begin{array}{l}\text { I. alpestris } \\
\text { Pelophylax spp. } \\
\text { L. helveticus }\end{array}$ & $\begin{array}{l}\text { Wood et al., } 2009 \\
\text { Wood et al., } 2009 \\
\text { Wood et al., } 2009\end{array}$ \\
\hline Macedonia & European water frog complex & Pelophylax spp. & Vojar et al., 2017 \\
\hline Montenegro & $\begin{array}{l}\text { Common or smooth newt } \\
\text { Edible frog complex } \\
\text { Great crested newt }\end{array}$ & $\begin{array}{l}\text { L. vulgaris } \\
\text { Pelophylax spp. } \\
\text { T. cristatus }\end{array}$ & $\begin{array}{l}\text { Vojar et al., } 2017 \\
\text { Vojar et al., } 2017 \\
\text { González et al., } 2019\end{array}$ \\
\hline
\end{tabular}




\begin{tabular}{|c|c|c|c|}
\hline Location & Common Name & Species & First Report \\
\hline Netherlands & $\begin{array}{l}\text { Alpine newt } \\
\text { Common midwife toad } \\
\text { Common frog } \\
\text { Common or smooth newt } \\
\text { Common toad } \\
\text { Edible frog } \\
\text { European water frog complex } \\
\text { European tree frog } \\
\text { Pool frog } \\
\text { Natterjack toad } \\
\text { Yellow-bellied toad }\end{array}$ & $\begin{array}{l}\text { I. alpestris } \\
\text { A. obstetricans } \\
\text { R. temporaria } \\
\text { L. vulgaris } \\
\text { B. bufo } \\
\text { P. esculentus } \\
\text { Pelophylax sp. } \\
\text { Hyla arborea } \\
\text { P. lessonae } \\
\text { Epidalea calamita } \\
\text { B. variegata }\end{array}$ & $\begin{array}{l}\text { Spitzen-van der Sluijs et al., } 2014 \\
\text { Spitzen-van der Sluijs et al., } 2014 \\
\text { Spitzen-van der Sluijs et al., } 2014 \\
\text { Spitzen-van der Sluijs et al., } 2014 \\
\text { Spitzen-van der Sluijs et al., } 2014 \\
\text { Spitzen-van der Sluijs et al., } 2014 \\
\text { Spitzen-van der Sluijs et al., } 2014 \\
\text { Spitzen-van der Sluijs et al., } 2014 \\
\text { Spitzen-van der Sluijs et al., } 2014 \\
\text { Spitzen-van der Sluijs et al., } 2014 \\
\text { Spitzen-van der Sluijs et al., } 2014\end{array}$ \\
\hline Poland & $\begin{array}{l}\text { Edible frog } \\
\text { European water frog complex } \\
\text { Pool frog } \\
\text { Yellow-bellied toad }\end{array}$ & $\begin{array}{l}\text { P. esculentus } \\
\text { Pelophylax sp. } \\
\text { P. lessonae } \\
\text { B. variegata }\end{array}$ & $\begin{array}{l}\text { Kolenda et al., } 2017 \\
\text { Sura et al., } 2010 \\
\text { Kolenda et al., } 2017 \\
\text { Kolenda et al., } 2017\end{array}$ \\
\hline Portugal & $\begin{array}{l}\text { Bosca's newt } \\
\text { Common midwife toad } \\
\text { Fire salamander } \\
\text { lberian green frog } \\
\text { lberian tree frog } \\
\text { Marbled newt } \\
\text { Spiny toad }\end{array}$ & $\begin{array}{l}\text { L. boscai } \\
\text { A. obstetricans } \\
\text { S. salamandra } \\
\text { P. perezi } \\
\text { Hyla molleri } \\
\text { Triturus marmoratus } \\
\text { B. spinosus }\end{array}$ & $\begin{array}{l}\text { Rosa et al., } 2017 \\
\text { Rosa et al., } 2013 \\
\text { Rosa et al., } 2017 \\
\text { Rosa et al., } 2017 \\
\text { Rosa et al., } 2017 \\
\text { Rosa et al., } 2017 \\
\text { Rosa et al., } 2017\end{array}$ \\
\hline Romania & $\begin{array}{l}\text { Common Frog } \\
\text { Smooth newt } \\
\text { Yellow-bellied toad }\end{array}$ & $\begin{array}{l}\text { R. temporaria } \\
\text { L. vulgaris } \\
\text { B. variegata }\end{array}$ & $\begin{array}{l}\text { Vörös et al., } 2013 \\
\text { Vörös et al., } 2013 \\
\text { Vörös et al., } 2013\end{array}$ \\
\hline Serbia & $\begin{array}{l}\text { Edible frog } \\
\text { Marsh frog } \\
\text { Pool frog }\end{array}$ & $\begin{array}{l}\text { P. esculentus } \\
\text { P. ridibundus } \\
\text { P. lessonae }\end{array}$ & $\begin{array}{l}\text { Mali et al., } 2017 \\
\text { Mali et al., } 2017 \\
\text { Mali et al., } 2017\end{array}$ \\
\hline Spain & $\begin{array}{l}\text { Betic midwife toad } \\
\text { Bosca's newt } \\
\text { Common midwife toad } \\
\text { Common toad } \\
\text { Fire salamander } \\
\text { Iberian green frog } \\
\text { Iberian painted frog } \\
\text { Majorcan midwife toad } \\
\text { Mediterranean tree frog } \\
\text { Natterjack toad } \\
\text { Spanish ribbed newt } \\
\text { Southern marbled newt } \\
\text { Western spadefoot toad }\end{array}$ & $\begin{array}{l}\text { A. dickhilleni } \\
\text { L. boscai } \\
\text { A. obstetricans } \\
\text { B. bufo } \\
\text { S. salamandra } \\
\text { P. perezi } \\
\text { Discoglossus galganoi } \\
\text { A. muletensis } \\
\text { H. meridionalis } \\
\text { E. calamita } \\
\text { Pleurodeles waltl } \\
\text { T. pygmaeus } \\
\text { Pelobates cultripes }\end{array}$ & $\begin{array}{l}\text { Bosch et al., } 2013 \\
\text { Hidalgo-Vila et al., } 2012 \\
\text { Bosch et al., } 2001 \\
\text { Bosch \& Martínez-Solano, } 2006 \\
\text { Bosch \& Martínez-Solano, } 2006 \\
\text { Hidalgo-Vila et al., } 2012 \\
\text { Hidalgo-Vila et al., } 2012 \\
\text { Garner et al., 2009a } \\
\text { Hidalgo-Vila et al., } 2012 \\
\text { Martínez-Solano et al., } 2003 \\
\text { Hidalgo-Vila et al., } 2012 \\
\text { Hidalgo-Vila et al., } 2012 \\
\text { Hidalgo-Vila et al., } 2012\end{array}$ \\
\hline Sweden & $\begin{array}{l}\text { Common frog } \\
\text { Common toad } \\
\text { Fire-bellied toad } \\
\text { Moor frog } \\
\text { Natterjack toad } \\
\text { Variable toad }\end{array}$ & $\begin{array}{l}\text { R. temporaria } \\
\text { B. bufo } \\
\text { B. bombina } \\
\text { R. arvalis } \\
\text { E. calamita } \\
\text { Bufotes variabilis }\end{array}$ & $\begin{array}{l}\text { Kärvemo et al., } 2018 \\
\text { Kärvemo et al., } 2018 \\
\text { Kärvemo et al., } 2018 \\
\text { Kärvemo et al., } 2018 \\
\text { Kärvemo et al., } 2018 \\
\text { Kärvemo et al., } 2018\end{array}$ \\
\hline Switzerland & $\begin{array}{l}\text { Alpine newt } \\
\text { Common midwife toad } \\
\text { European water frog complex } \\
\text { Palmate newt }\end{array}$ & $\begin{array}{l}\text { I. alpestris } \\
\text { A. obstetricans } \\
\text { Pelophylax sp. } \\
\text { L. helveticus }\end{array}$ & $\begin{array}{l}\text { Tobler et al., } 2012 \\
\text { Tobler et al., } 2012 \\
\text { Tobler et al., } 2012 \\
\text { Tobler et al., } 2012\end{array}$ \\
\hline UK & $\begin{array}{l}\text { African clawed frog } \\
\text { American bullfrog } \\
\text { Natterjack toad }\end{array}$ & $\begin{array}{l}\text { Xenopus laevis } \\
\text { Lithobates catesbeianus } \\
\text { E. calamita }\end{array}$ & $\begin{array}{l}\text { Tinsley et al., } 2015 \\
\text { Garner et al., } 2005 \\
\text { May et al., } 2011\end{array}$ \\
\hline
\end{tabular}

Table 2. Summary of the countries and amphibian species affected by Batrachochytrium salamandrivorans infections in wild European populations.

\begin{tabular}{llll}
\hline Location & Common Name & Species & First Report \\
\hline Belgium & Alpine newt & Ichthyosaura alpestris & Spitzen-van der Sluijs et al., 2016a \\
& Fire salamander & Salamandra salamandra & Spitzen-van der Sluijs et al., 2016a \\
Germany & Fire salamander & S. salamandra & Spitzen-van der Sluijs et al., 2016a \\
Netherlands & Alpine newt & I. alpestris & Spitzen-van der Sluijs et al., 2016a \\
& Smooth newt & Lissotriton vulgaris & Spitzen-van der Sluijs et al., 2016a \\
Spain & Fire salamander & S. salamandra & Martel et al., 2013 \\
& Palmate newt & L. helveticus & González et al., 2019 \\
\hline
\end{tabular}


Table 3. Summary of countries and amphibian species affected by herpesvirus infections in wild European populations.

\begin{tabular}{llll}
\hline Location & Common Name & Species & First Report \\
\hline Germany & Common frog & Rana temporaria & Mutschmann \& Scheenweiss, 2008 \\
& Moor frog & R. arvalis & Mutschmann \& Scheenweiss, 2008 \\
& European spadefoot toad & Pelobates fuscus & Mutschmann \& Scheenweiss, 2008 \\
Italy & Agile frog & R. dalmatina & Bennati et al., 1994 \\
Switzerland & Common frog & R. temporaria & Origgi et al., 2017 \\
& Common toad & Bufo bufo & Origgi et al., 2018 \\
UK & Common frog & R. temporaria & Franklinos et al., 2018 \\
\hline
\end{tabular}

The salamander chytrid fungus (Batrachochytrium salamandrivorans, hereafter Bsal) was first identified in 2013 after a dramatic loss of European fire salamanders (Salamandra salamandra) in the Netherlands (Martel et al., 2013; Spitzen-van der Sluijs et al., 2013). The fungus itself is closely related to $B$. dendrobatidis, having diverged sometime in the late Cretaceous or early Paleogene (Martel et al., 2014). The introduction pathway of the pathogen to Europe is believed to have been via the trade in Asian newt species, with Bsal being the predominant chytrid fungus affecting Vietnamese salamanders (Laking et al., 2017). There is also alternative evidence to support the introduction of Bsal to Europe through the trade in small-webbed fire-bellied toads (B. microdeladigitora) from Vietnam (Nguyen et al., 2017). In lab experiments, Asian newts (Cynops cyanurus, C. pyrrhogaster \& Paramesotriton deloustali) were discovered to be potential reservoirs of $B s a l$, and worryingly, most European newts died shortly after infection with Bsal (Martel et al., 2014). Recent evidence suggests that one of the factors that makes Bsal such a threat to urodelean diversity is the fact that infection does not elicit immunity and anurans, such as the common midwife toad ( $A$. obstetricans), may act as intermediary hosts (Stegen et al., 2017). More worryingly, alpine newts (Ichthyosaura alpestris) can survive for extended periods of time whilst infected with low doses of Bsal, with the ability to even clear infection. This is a concern as alpine newts co-occur with $S$. salamandra whilst A. obstetricans does not (Stegen et al., 2017).

The clinical signs of $B s a l$ are varied (like those of $B d$ ) but are usually seen as anorexia, lethargy, ataxia, and skin lesions (Martel et al., 2013). The skin lesions (Fig. 3) are quite diagnostic and easily identified on adult individuals (although this varies by species); however, they are not always present and tend to occur at the end of pathogenesis when the animal is nearly dead (Martel et al., 2013). This means that detailed histological and genetic analyses are needed to confirm the presence of $B s a l$ in a suspected infected individual. Again, the standard technique for detection, like $B d$, is the use of swabs and qPCR.

In the wild, $B s a$ / has been only found in a small number of European countries (Table 2) although the presence of the fungus is known to be more widespread in private collections (Fitzpatrick et al., 2018; Sabino-Pinto et al., 2015). It is vital that private collectors take the necessary biosecurity protocols when disinfecting wastewater and enclosures. More information can be found in Van Rooij et al. (2017). Despite the potentially devastating effects of $\mathrm{Bsal}$ on naive populations, $\mathrm{Bsal}$ has a poor dispersal potential which allows some sub-populations to persist in areas where the pathogen is known to be present (Spitzen-van der Sluijs et al., 2018). As highlighted by Spitzen-van der Sluijs et al. (2018), this provides potential for in-the-field mitigation strategies and also shows the importance of biosecurity to ensure that researchers are not accidentally transferring $B s a l$ zoospores between sites.

At this time, $\mathrm{Bsal}$ is limited to wild populations in

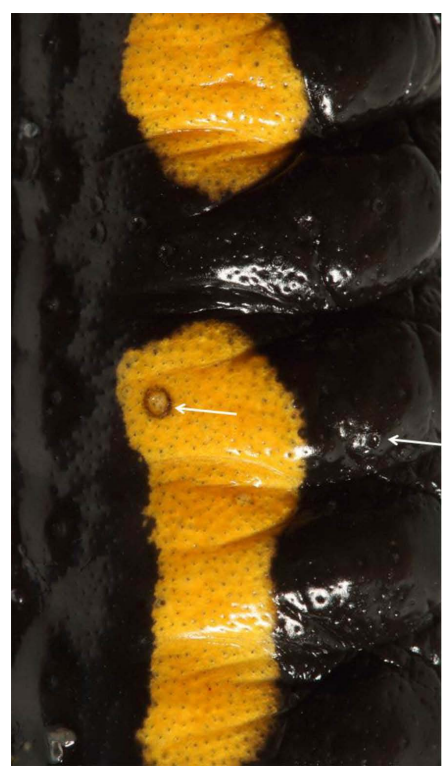

Figure 3. Close up of the skink of a fire salamander (S. salamandra) that died because of Bsal caused chytridiomycosis. Note the skin erosion with black margins indicated by the white arrows. Photo By: Frank Pasmans.

Germany, Belgium, Spain and the Netherlands (Fig. 4). In Bsal's range the species of focus is the European fire salamander (S. salamandra) although other species have also tested positive for $\mathrm{Bsal}$ (Table 2). In order to track the pathogen's spread through Europe, ongoing surveillance needs to carried out in areas that may be susceptible to spillover, as well as monitoring vulnerable species. Limited screening in the Czech Republic revealed that $B s a l$ was not present in wild or captive salamanders (Baláz et al., 2018), although more samples are needed 


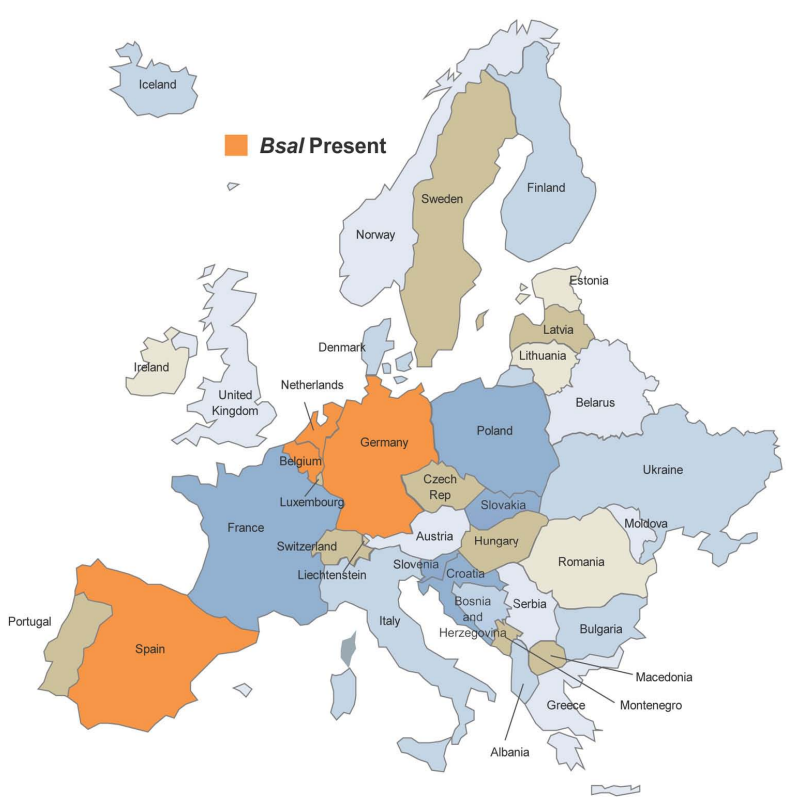

Figure 4. The distribution of Batrachochytrium salamandrivorans (Bsal) in wild European amphibian populations.

to ensure that $B s a l$ is not present within the country. Ongoing surveillance is needed to ensure the emergence of $\mathrm{Bsal}$ is not missed in areas where it has not yet been recorded in the wild. This surveillance can be either active or passive, depending on the time and resources available. Recently in the UK, 2,409 swabs collected from wild newts in 2011 and 43 newts submitted for postmortem examination (between March 2013-December 2017) all tested negative for Bsal (Cunningham et al., 2019). However, there is experimental evidence to suggest that salamanders infected with low loads of $B s a l$ may go undetected due to latency in detection via qPCR (Thomas et al., 2018). Due to the nature of the pathogen, screening should be completed regularly, especially of those populations that are deemed most vulnerable to ensure that there are no false negatives. In addition to this, to prevent the spread of the pathogen within Europe from captive collections, we advocate the trade in captive bred, certified disease-free salamanders only. Furthermore, the use of the early warning system developed for Bsal in Europe should be used (see below for more information).

\section{HERPESVIRUSES}

It is thought that amphibian herpesviruses are widely distributed in Europe (Garner et al., 2013); however, they have received relatively little attention in the literature and therefore we cannot determine its status as emergent, although reports appear to be on the rise. The first disease associated with herpesvirus-like particles in an amphibian species reported in Europe occurred in the early 1990s and was published by Benatti et al. (1994). They reported herpesvirus-like particles in agile frogs (Rana dalmatina) from Italy suffering from herpes-like lesions. However, the outbreak was not accompanied by a mortality event (Benatti et al., 1994). Subsequently, amphibian herpesviruses have been reported in Germany,

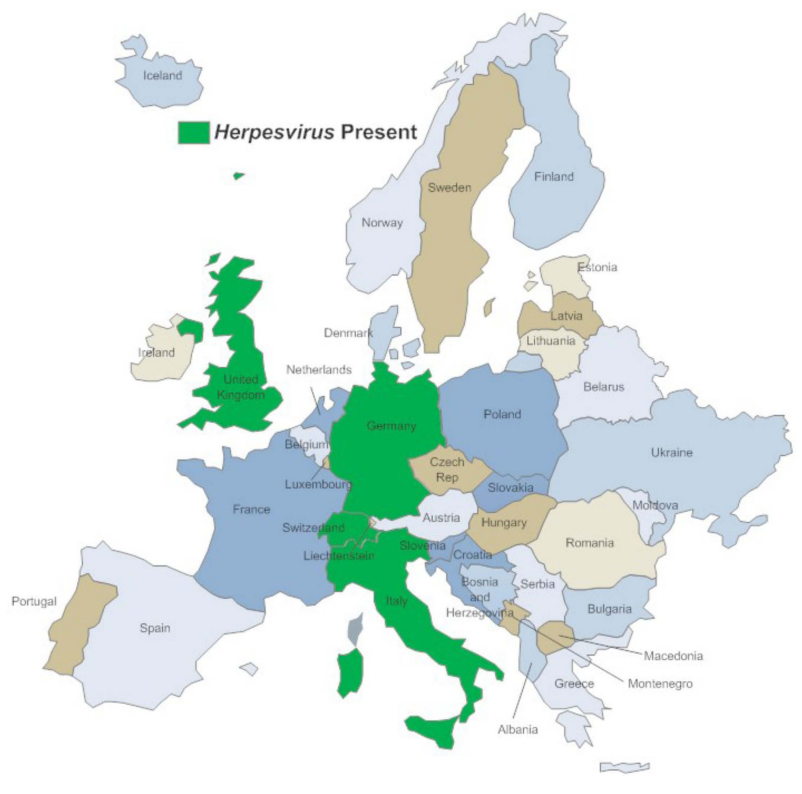

Figure 5. The distribution of amphibian herpesviruses in wild European amphibian populations.

Switzerland, and the UK in five different species, one of conservation concern (Pelobates fuscus, Mutschmann \& Scheenweiss, 2008, and see Table 3 and Fig. 5).

The gross clinical signs of amphibian herpesvirus infections appear to be conserved across affected species. Typically, lesions are present on the skin that may be tan (more terrestrial species), grey, or grey-blue in colour (typical of more aquatic species; see Origgi et al., 2017; Franklinos et al., 2018; Origgi et al., 2018). These are areas where the skin has become thickened and they may appear on any region of the body (Origgi et al., 2017; Franklinos et al., 2018; Origgi et al., 2018). The number of lesions that appear on the skin of affected animals is often variable, ranging from one to covering most of the skin (Origgi et al., 2017; Franklinos et al., 2018; Origgi et al., 2018; Fig. 6).

There are two species of amphibian herpesvirus known to be present in Europe and both were first described in Swiss amphibians. Origgi et al. (2017) identified and characterised Ranid Herpesvirus 3 (RaHV3) from common frogs ( $R$. temporaria) that were suffering from a proliferative dermatitis. Subsequently, Origgi et al. (2018) described Bufonid Herpesvirus 1 (BfHV1) in common toads (B. bufo) that were also suffering from dermatitis. These are the first amphibian herpesviruses outside of North America to be fully characterised and described in wild caught amphibians. Additionally, Franklinos et al. (2018) found herpesvirusassociated dermatitis in common toads. However, the virus(es) present in UK amphibians was/were not fully characterised, so it is unknown if two different virus species are present.

The threat of amphibian herpesviruses to European amphibian populations is unknown. Their ability to cause infection and subsequent mortality in $P$. fuscus is a cause for concern (Garner et al., 2013). More research is needed to fully understand the effects of viral 


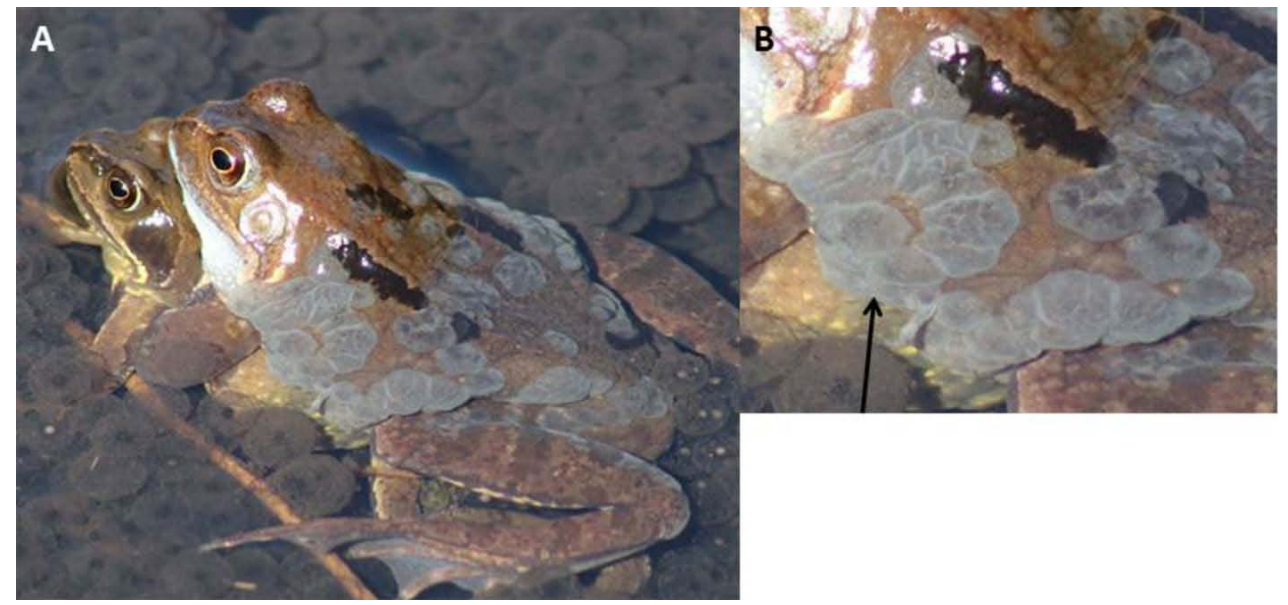

Figure 6. (A) Herpesvirus infection in a male common frog (R. temporaria) from the UK. Note the grayish nature of the lesions that are distributed on the dorsal aspect of the frog. (B) Close up of the herpesvirus lesions on the dorsum of the same male common frog. Note the 'fluid filled' appearance of the lesions. Photo by Matthew Chester.

persistence in populations of affected amphibians. It will be important for interdisciplinary teams to investigate amphibian herpesviruses because of the difficulties that are often encountered with proper identification and diagnosis (see Garner et al., 2013 for further discussion).

\section{RANAVIRUSES}

Amphibian ranaviruses are widely distributed in Europe. They are currently known to be present in over ten countries and in over ten amphibian species (see Table 4 and Fig. 7). Amphibian ranaviruses belong to the viral family Iridoviridae, which are large, double stranded DNA viruses (Chinchar et al., 2017). In fact, the first documented cases of what were likely to be Ranavirus infections were broadly identified as iridovirus-like agents. Fijan et al. (1991) found iridovirus-like particles in edible frogs (Pelophylax esculentus) from a population that experienced a mortality event in Croatia. This discovery was quickly followed by the identification of an iridovirus-like agent associated with morbidity and mortality events in UK common frogs (Rana temporaria), that was eventually classified as a Ranavirus (Cunningham et al., 1993; Cunningham et al., 1996; Drury et al., 1995). Despite the early report of an iridovirus-like agent in Croatia, no subsequent reports of amphibian ranaviruses can be found in the literature for continental Europe until a new Ranavirus species emerged in 2007 (see below for further discussion).

The gross clinical signs of ranaviral disease are conserved across species and life history stages. It is important to note that not all ranaviral infections will result in disease, and therefore the absence of gross clinical signs should not be taken as a clean bill of health (see Rijks et al., 2016). Additionally, in most cases, the gross signs of ranavirosis are considered to be nonspecific to the disease, and therefore it is imperative that a full and proper pathological investigation be performed when infection or disease is thought to be a contributing factor to a morbidity and/or mortality event. Gross clinical signs of ranavirosis of juvenile and adult amphibians include, but are not limited to: lethargy, skin ulcerations, haemorrhages in the skin, reddening of the skin, necrosis of digits, and internal haemorrhages of multiple organ systems (predominantly the gastrointestinal tract and reproductive tracts; Cunningham et al., 1996; Cunningham et al., 2007a; Cunningham et al., 2007b; Price et al., 2014; see Figure 8 and images in Duffus \& Cunningham, 2010). The signs of disease in affected tadpoles/larvae included systemic external and internal haemorrhages (Balseiro et al., 2009; Balseiro et al., 2010). External haemorrhages occur predominantly in the tissues surrounding the eyes of the tadpoles and in the tail, including the musculature (Balseiro et al. 2009; Balseiro et al., 2010) and edema has also been observed (Rosa et al., 2017). Infection, disease, and mortality can occur at any life history stage in amphibians, except for the egg stage. However, the life history stage affected seems to be species specific. In some species, it is the adults that are predominantly affected [e.g. common frogs (R. temporaria, Cunningham et al., 1996)] whereas in other species, the larvae/tadpoles are affected [e.g. common midwife toads ( $A$. obstetricans) and Alpine newts (I. alpestris) (Balseiro et al., 2009; Balseiro et al., 2010)].

There are several different types of Ranavirus that are present in Europe. Frog virus 3 (FV3), Common midwife toad virus (CMTV), and their derivatives appear to be the most common types of ranaviruses present in amphibians. FV3 is the type virus of the genus Ranavirus (Tan et al., 2004) and is perhaps the most common species of Ranavirus around the globe in amphibian populations (see Duffus et al., 2015). However, CMTV-like viruses are known to recombine with FV3-like strains and can create extremely virulent chimeric viruses (Claytor et al., 2017). Experimental infection of smooth newts (Lissotriton vulgaris) with different strains of CMTV Ranavirus from the Netherlands clearly demonstrates distinct strainassociated pathogenicity within closely related strains of the virus (Saucedo et al., 2019).

The emergence of amphibian ranaviruses and likely misdiagnosis as 'red-leg syndrome' in Europe has had a measurable negative effect on some, but not all, populations. The first well-documented morbidity and mortality event in continental Europe occurred in 2007 
Table 4. Summary of countries and amphibian species known to harbour Ranavirus infections in wild European populations.

\begin{tabular}{|c|c|c|c|}
\hline Location & Common Name & Species & First Report \\
\hline \multirow[t]{2}{*}{ Belgium } & Common toad & Bufo bufo & Martel et al., 2012 \\
\hline & American bullfrog & Lithobates catesbeianus & Sharifian-Fard et al., 2011 \\
\hline Croatia & Edible frog & Pelophylax esculentus & Fijan et al., 1991 \\
\hline Denmark & Edible frog & P. esculentus & Ariel et al., 2009 \\
\hline France & Common frog & Rana temporaria & Miaud et al., 2016 \\
\hline Germany & Edible frog & P. esculentus & Stöhr et al., 2013 \\
\hline Italy & Edible frog & P. esculentus & Holopainen et al., 2009 \\
\hline \multirow[t]{6}{*}{ Netherlands } & European water frog complex & Pelophylax spp. & Kik et al., 2011 \\
\hline & Smooth newt & Lissotriton vulgaris & Kik et al., 2011 \\
\hline & Common frog & Rana temporaria & Rijks et al., 2016 \\
\hline & Common toad & B. bufo & Rijks et al., 2016 \\
\hline & European spadefoot toad & Pelobates fuscus & Spitzen-van der Sluijs et al., 2016c \\
\hline & Great crested newt & Triturus cristatus & Spitzen-van der Sluijs et al., 2016c \\
\hline \multirow[t]{6}{*}{ Portugal } & Common midwife toad & Alytes obstetricans & Stöhr et al., 2015 \\
\hline & Bosca's newt & L. boscai & de Matos et al., 2008 \\
\hline & Spiny toad & B. spinosus & Rosa et al., 2017 \\
\hline & Fire salamander & Salamandra salamandra & Rosa et al., 2017 \\
\hline & Iberian tree frog & Hyla molleri & Rosa et al., 2017 \\
\hline & Marbled newt & T. marmoratus & de Matos et al., 2008 \\
\hline \multirow[t]{5}{*}{ Spain } & Common midwife toad & A. obstetricans & Balseiro et al., 2009 \\
\hline & Common frog & R. temporaria & Price et al., 2014 \\
\hline & Alpine newt & Ichthyosaura alpestris & Balseiro et al., 2010 \\
\hline & Bosca's newt & Lissotriton boscai & Price et al., 2014 \\
\hline & Marbled newt & T. marmoratus & Price et al., 2014 \\
\hline Switzerland & Marsh frog & P. ridibunda & Stöhr et al., 2015 \\
\hline \multirow[t]{4}{*}{ UK } & Common frog & R. temporaria & Drury et al., 1995 \\
\hline & Common toad & B. bufo & Hyatt et al., 2000 \\
\hline & Common midwife toad & A. obstetricans & Duffus et al., 2014 \\
\hline & Smooth newt & L. vulgaris & Duffus et al., 2014 \\
\hline
\end{tabular}

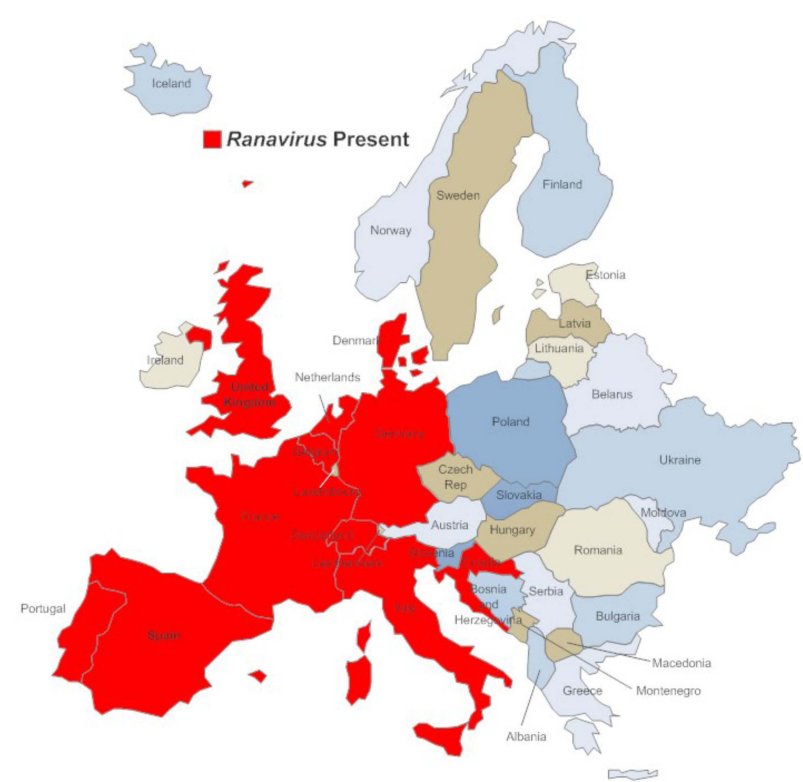

Figure 7. The distribution of Ranavirus spp. in wild European amphibian populations.

in 'Picos de Europa' National Park, Spain (Balseiro et al., 2009). The mortality event involved common midwife toad ( $A$. obstetricans) tadpoles that showed classic signs of ranavirosis (Balseiro et al., 2009). Investigations into the cause of the mortality event revealed that it was caused by a novel Ranavirus, then tentatively called the common midwife toad virus (CMTV, Balseiro et al., 2009) and CMTV was only recently designated as its own species in the genus Ranavirus (Chinchar et al., 2017). The following year, CMTV was responsible for another morbidity and mortality event. This time not only did it affect common midwife toad tadpoles, but also alpine newt (I. alpestris cyreni) larvae (Balseiro et al., 2010). Since then, declines and local extirpations of several species have been documented in association with the emergence of ranaviruses in the same park. Price et al. (2014) found that at several locations, common midwife toads ( $A$. obstetricans) were extirpated and both alpine newts (I. alpestris) and common toads (B. bufo) experienced severe declines. Unfortunately, it does not appear that the populations are recovering from the effects the emergence of ranaviral infection and disease at this time (Price et al., 2014). Many more outbreaks of ranavirosis have now been documented across continental Europe. Perhaps the largest scale morbidity and mortality event involving a CMTV-like virus occurred in 2010 in the Netherlands (Kik et al., 2011; van Beurden et al., 2014). The event involved more than 1000 individuals, mostly 

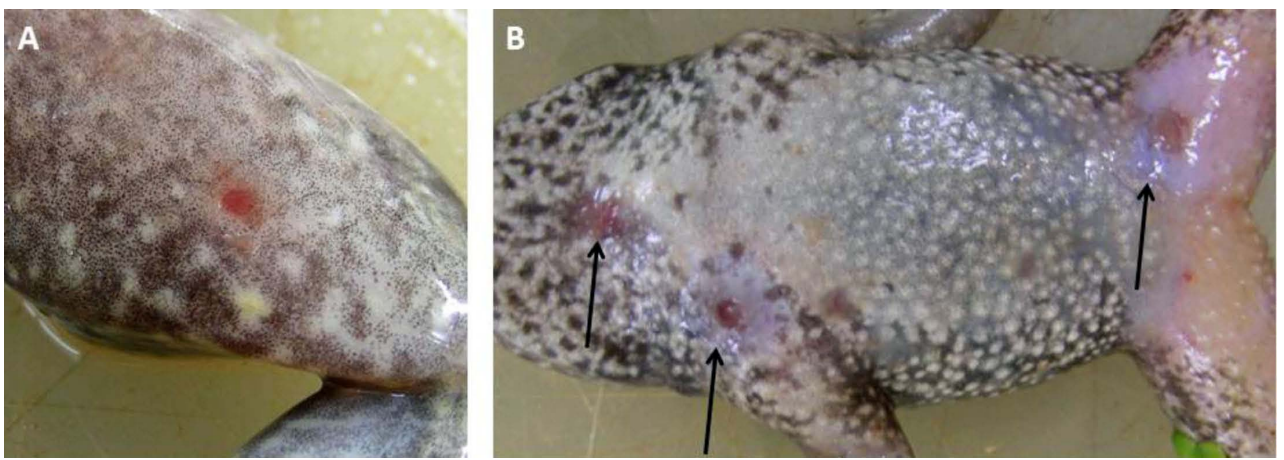

Figure 8. (A) Ranavirus-associated ulceration on the upper portion of the leg of a common frog (R. temporaria) from the UK. (B) Ranavirus-associated ulcerations in a common midwife toad (A. obstetricans) from the UK. Arrows indicate the lesions. Note the greyish area around the ulcerations. Photos by Zoological Society of London/Amanda L.J. Duffus

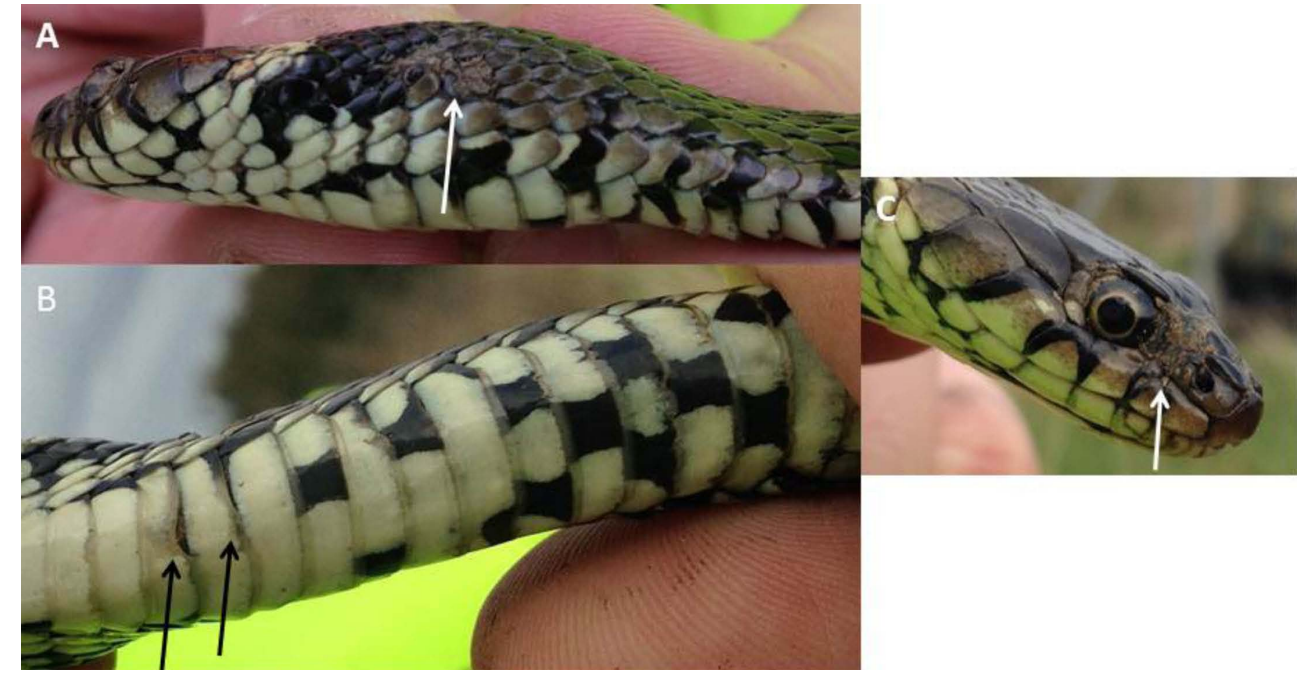

Figure 9. A barred grass snake (N. helvetica) in from the UK with suspected ophidiomycosis. (A) Arrow indicates the 'crusty' scales that are common in snakes suffering from ophidiomycosis. (B) Arrows indicate some of the deformed scales frequently seen in snakes with ophidiomycosis. (C) The arrow indicates the crusty scales on the snout. Photos by Silviu Petrovan.

Pelophylax spp. but some common newts (L. vulgaris; Kik et al., 2011). Subsequent investigations into amphibian morbidity and mortality events in the Netherlands has revealed that the CMTV-like Ranavirus is spreading and is the causative agent of many of the observed events (Rijks et al., 2016; Spitzen-van der Sluijs et al., 2016b; Saucedo et al., 2018). It is also important to note that these outbreaks of disease are affecting the common spadefoot ( $P$. fuscus), which is a threatened species (Spitzen-van der Sluijs et al., 2016c). In the UK, common frog populations where ranaviruses have emerged have significantly decreased in size. Teacher et al. (2010) found that on average, common frog populations where Ranavirus was found declined by approximately $81 \%$ when compared to populations where the virus was absent. Furthermore, Teacher et al. (2010) report that larger populations were disproportionately affected, with larger populations losing a greater number of animals to disease emergence than those that were initially smaller when Ranavirus infections emerged. The emergence of amphibian ranaviruses has also changed the population structure of common frogs in the UK, making them more susceptible to stochastic events (Campbell et al., 2018). This is cause for great concern with the ever-increasing random events that climate change will cause. Thus, the emergence of ranaviruses in European amphibians is a cause for great conservation concern. They have the potential to be lethal pathogens and are now known to drive populations to decline or even local extinction (e.g. Teacher et al., 2010, Price et al., 2014, Rosa et al., 2017), as a single responsible agent or in co-occurrence with for instance $B d$ and/or Bsal. Ranaviruses are persistent pathogens, meaning that they remain on field gear far longer than Bd or Bsal (Nazir et al., 2012; Van Rooji et al., 2017); therefore, proper disinfection methods should always be used on field gear and enhanced biosecurity in facilities where the pathogen may be found. Investigating amphibian health and disease should be made a priority for many species, even common ones, and include an interdisciplinary approach to ensure that these animals have a future.

The effects of the emergence of ranaviruses may be compounded when another disease, such as $B d$, has emerged previously in a population. In the 'Serra da Estrela' Natural Park, $B d$ related declines of amphibian populations were occurring for many years before ranavirosis emerged (Rosa et al., 2017). Ranavirosis was first documented in 2011 and is now known to occur in 
Table 5. Summary of the countries and snake species affected by snake fungal disease (Ophidiomyces ophiodiicola) infections in wild European populations.

\begin{tabular}{llll}
\hline Location & Common Name & Species & First Report \\
\hline Czech Republic & Dice snake & Natrix tessellata & Franklinos et al., 2017 \\
Switzerland & Grass snake & N. natrix & Meier et al., 2018 \\
UK & Barred grass snake & N. helvetica & Franklinos et al., 2017 \\
& Adder & Vipera berus & Franklinos et al., 2017 \\
\hline
\end{tabular}

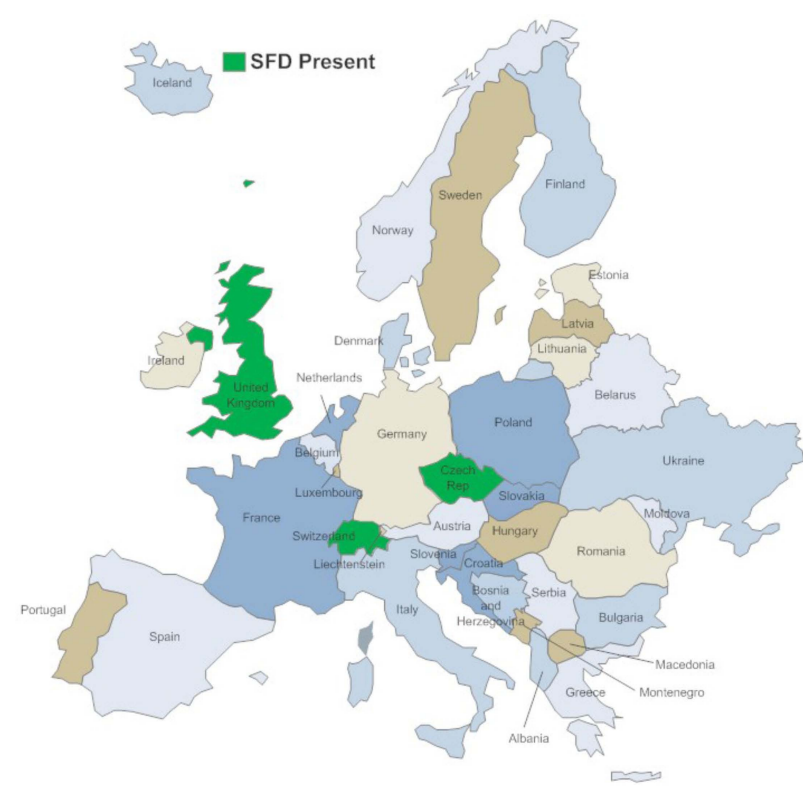

Figure 10. The distribution of ophidiomycosis cases in wild European snake populations.

several species (T. marmoratus, A. obstetricans, L. boscai, S. salamandra, and B. spinusus, Rosa et al., 2017). The emergence of ranavirosis was correlated with sharp declines in two species ( $L$. boscai and A. obstetricans) at one of the sites within Serra da Estrela Natural Park (Rosa et al., 2017). The ability of Ranavirus emergence in amphibians to change the species assemblages at a site and alter host community composition and structure is a huge threat to these animals (Rosa et al., 2017). Therefore, surveillance efforts must not just be centred around one potential pathogen or one potential host; a community-based approach for pathogen surveillance should be used whenever possible.

\section{EMERGING INFECTIOUS DISEASE THREATS TO REPTILES OPHIDIOMYCOSIS/SNAKE FUNGAL DISEASE}

In recent years it has become apparent that amphibians are not the only herptiles to suffer from declines caused by emerging fungal pathogens. There are a number of minor fungal diseases that infect reptiles (Paré \& Sigler, 2016) but the one that has recently caught international attention is snake fungal disease. The causative agent was first identified in 2009 as Chrysosporium ophiodiicola (Rajeev et al., 2009) but subsequent research has seen the fungus moved to its own genus of Ophidiomyces (Sigler et al., 2013). Commonly known as snake fungal disease (hereafter SFD) but more correctly know as ophidiomycosis, is troubling for many reasons, one of which is that the clinical signs are not pathognomonic and so histological evidence, as well as genetic, is needed to confirm infection. SFD was first identified from snakes in the US (Dolinski et al., 2014; Rajeev et al., 2009) and it has recently been found to be present in snake populations in Europe (Franklinos et al., 2017; Meier et al., 2018).

The clinical signs of ophidiomycosis vary slightly between species but include skin lesions, dermatitis, scale deformity and yellow-brown crusty areas (Lorch et al., 2016). Abrasion may create opportunities for infection. Once the stratum corneum has been compromised, $O$. ophiodiicola can then quickly penetrate the epidermis, at which point the hosts immune response leads to the aforementioned clinical signs developing (see Fig. 9; Lorch et al., 2015). As a response to the disease, snakes tend to increase their sloughing frequency in order to try to cast off the pathogen. The new skin underneath is clinically normal and this behaviour may lead to snakes successfully curing themselves of ophidiomycosis. However, if old skin is stuck to the new skin during a shed, then there is the potential for reinfection (Lorch et al., 2015). All of this is very worrying for snake species that may already be suffering from the effects of fragmentation, persecution, and inbreeding depression (Madsen et al., 1996; Ursenbacher et al., 2009). The current evidence suggests that $O$. ophiodiicola only has the ability to infect snakes, although this is an area that needs further investigation.

So far, investigations into the presence of ophidiomycosis in the Europeare limited, but the presence has been confirmed in a number of species in a small number of countries (Table 5, Fig. 10). The first evidence of ophidiomycosis being present in Europe came from a screening of archived specimens collected by the Garden Wildlife Health project between 2010-2016 (Franklinos et al., 2017). This effort identified that wild European snakes in two countries (the UK and Czech Republic) were positive for $O$. ophiodiicola using a combination of histological and genetic diagnostic techniques. Since then, snakes from Switzerland have also tested positive for the causative agent of ophidiomycosis (Meier et al., 2018). At this stage it is not known how virulent the disease is to European snake species. Franklinos et al. (2017) noted that skin lesions were mild in most of the cases they examined but in some, these lesions were quite severe and would have contributed to the animals mortality. At this time, we do not have a clear picture of how widespread ophidiomycosis is in Europe or what that means for its snake species. More research is needed to help understand the status of this pathogen. In particular, it is not known whether or not ophidiomycosis is an 
Table 6. Summary of countries and reptile species known to harbour Ranavirus infections in wild European populations.

\begin{tabular}{llll}
\hline Location & Common Name & Species & First Report \\
\hline Portugal & Iberian mountain lizard & Iberolacerta monticola & Alves de Matos et al., 2011 \\
Spain & Viperine snake & Natrix maura & Price et al., 2014 \\
UK & Slow worm & Anguis fragilis & Price et al., 2017 \\
\hline
\end{tabular}

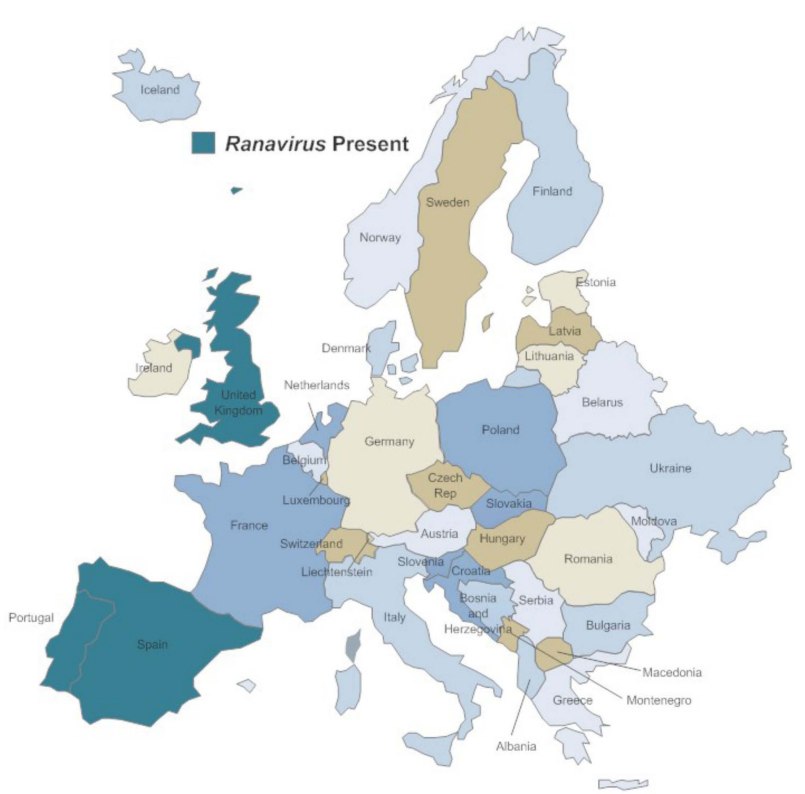

Figure 11. The distribution of Ranavirus spp. in wild European reptile species.

endemic disease that has become more virulent due to recent changes or whether it is introduced. Genetic work conducted by Franklinos et al. (2017) demonstrates that the strains of ophidiomycosis in Europe are different to those in the US, but again further research is needed to fully understand this relationship.

\section{RANAVIRUSES}

Amphibians are not the only group of poikilothermic vertebrates to be affected by ranaviruses; both fish and reptiles are also susceptible. In Europe, most cases of Ranavirus infections in reptiles have been reported in captive populations (see Duffus et al., 2015). There are only three reports of Ranavirus infections in wild European reptiles in three different species; however, it is extremely likely that this is not reflective of the actual situation (see Table 6 and Fig. 11).

Signs of ranavirosis in reptilians are diverse and nonspecific, including but not limited to: lethargy, anorexia, upper respiratory tract necrosis, edema (especially in the region of the neck), dermatitis, and nasal discharge (Marschang, 2011). Most reptilian Ranavirus infections have actually been reported in testudinids, with comparatively few in squamates (see Duffus et al., 2015). Since the gross signs of ranavirosis in reptiles are diverse, it is important for a full pathological investigation to be undertaken when disease is thought to be the cause of mortality. The first confirmed report of an iridoviruslike virus was documented in an Iberian mountain lizard (Lacerta monticola) from 'Serra da Estrela', Portugal (Alves de Matos et al., 2011). The animal was asymptomatic and released after a blood sample was taken (Alves de Matos et al., 2011; Stöhr et al., 2015). A Ranavirus spp. was isolated from this blood sample and it was shown to be an FV3-like virus (Alves de Matos et al., 2011; Stöhr et al., 2015). A report of a Ranavirus infection in a slow worm (Anguis fragilis) is made in Price et al. (2017) but very little information about the affected animal was provided. However, in 2014, a more concerning report of a Ranavirus infection in a reptile was published. Price et al. (2014) report the first Ranavirus-associated mortality in a wild European reptile. A CMTV-like Ranavirus was isolated from a dead viperine snake (Natrix maura), from 'Picos de Europa' National Park, Spain, that had been scavenging on amphibians from a Ranavirus-associated mortality event (Price et al., 2014). This underscores the ability of ranaviruses to infect multiple hosts from different taxa and is a further demonstration of how severe a threat to herpetofauna that this group of pathogens is.

\section{GENERAL RESOURCES FOR STUDYING HERPETOFAUNAL INFECTIOUS DISEASES}

In the past decade, there have been a number of important resources published that examine different aspects of the study of herpetofaunal infectious diseases. Gray et al. (2017) provides an in-depth methodology on pathogen surveillance specifically for herpetofauna. They examine how to design a surveillance study, how to collect samples to perform the study, biosecurity, and even intervention strategies for when an emerging infectious disease has been detected. Gray et al. (2017) is a valuable resource for those seeking to improve study design and limit the spread of infectious diseases in herpetofauna. Langwig et al. (2015) provide an excellent resource for examining the emergence of infectious diseases in wildlife. They provide a framework for decision making and necessary actions pre-and post-infection detection.

Few resources for wildlife professionals have been developed that deal with necropsy techniques, as most have been written for veterinary professionals. While we encourage multidisciplinary teams that include veterinary pathologists, necropsies of herpetofauna may also be carried out by trained wildlife professionals. Duffus et al. (2017) provides a guide for investigating herpetofaunal mortality events. The manuscript is geared towards wildlife professionals and provides methods for necropsies, tissue sample collection, and sample storage and shipping. There are also publications that specifically deal with the detection and diagnosis of specific pathogens. For example, Thomas et al. (2018) examines the current diagnostic tools available for Bsal. They provide guidelines not only for the use of these 
tools, but also for interpreting the results that these tools provide (Thomas et al., 2018). It is incredibly important to standardise both the methodologies and the interpretation of their results to ensure that results from different studies can be easily and consistently compared. Unfortunately, not all studies follow these guidelines and this leads problems in comparing results. For example, Dalbeck et al. (2018) uses a significance threshold of $0.05 \mathrm{GE}$ when testing for Bsal, whereas a threshold of $0.1 \mathrm{GE}$ is recommended by Thomas et al. (2018), when diluting extracted samples prior to qPCR. This of course, will lead to confusion and a difference in results when comparing studies unless there is a universally agreed standard, such is recommended in the case of Bd (Boyle et al., 2004; Blooi et al., 2013).

In addition to print resources, there are online databases that have been developed to track some emerging infections of herpetofauna. The Amphibian Disease Portal (https://amphibiandisease.org) is a database that is used to track reports of $B d$ and $B s a l$ around the globe. Additionally, there is a Bsal reporting system for Europe (www.BsalEurope.com) and an associated early warning system. The Bsal reporting system and the early warning system for Europe will be extremely important in tracking infections and mitigating the effects of Bsal once it is found in an area. The Global Ranavirus Reporting System (https://mantle.io/grrs) is another online database that tracks reports of Ranavirus infection around the globe. These are both relatively new online databases and rely on researchers to upload their data into the system. To ensure that these resources are viable, we encourage researchers to upload their published data to these sites. An older resource that has been previously been used to track the global emergence of $B d$ is www.bd-maps.net (Olson et al., 2013). There are over 40,000 entries from over 80 countries in this database.

Ranaviruses, $B s a l$, and $B d$ are all reportable infections in amphibians (see http://www.oie.int/animal-healthin-the-world/oie-listed-diseases-2019/ for a list of reportable infections). The OIE (http://www.oie.int/) has specific guidelines for reporting these infections and they should be reported to the appropriate agency in the country that they are discovered in. Additionally, risk analyses may be performed and there are several sources for guidelines, including Jackob-Hoff et al. (2014) and one jointly published by the OIE and IUCN (OIE and IUCN 2014). These are invaluable resources for anyone who deals with infectious diseases in wildlife.

\section{CONCLUDING REMARKS}

With the global declines of both amphibians and reptiles, it is now more important than ever to understand the threats to these unique and important animals. Although we have only focused on five emerging infectious disease threats to these animals in Europe, there are likely more (e.g. Amphibiocystidium, identified in Duffus \& Cunningham, 2010), that are understudied and poorly understood, or even unknown infections that are taking a toll on the populations of these animals. Unfortunately, as stated above, the emergence of several of these infectious diseases has resulted in population declines and local extirpations of several species, some of which were rare, but others, more worryingly, were considered to be common.

An important and necessary difference between the infection status of an animal and the appearance of clinical signs of disease is still often overlooked in many studies in herpetofauna. Infection is the presence of the potentially pathogenic or disease-causing agent in an organism or population, whereas disease is a measurable negative effect that the infection process has imposed in an animal (Scott, 1988). The effects of an infection may or may not result in the development of clinical signs of disease (Scott, 1988). Usually, disease is measured by the appearance of clinical signs. However, the presence/ absence of these signs are often dependent upon the scale at which one is examining the organism (Scott, 1988).

Recent research has focused on both the imperfect detectability of infectious diseases (such as $B d$ ) when using swabs and qPCR (DiRenzo et al., 2018) as well as the costs involved to complete the analysis (SabinoPinto et al., 2018). As previously mentioned, qPCR isn't infallible and false-positive or false-negative results are always possible. We therefore recommend that multiple detection techniques be used in order to be certain when screening suspected infected individuals. In order to fully understand the effects that emerging infectious diseases have on populations, an interdisciplinary team, as stressed in Duffus and Cunningham (2010), should be used. Ideally, such a team would include ecologists, herpetologists, population biologists, and veterinary pathologists. The team should investigate the entire situation, sometimes including multiple species in an area, to garner a deeper understanding of the issues that are potentially being caused by the emergence of an infectious agent.

\section{ACKNOWLEDGEMENTS}

We would like to thank Matthew Chester, Silviu Petrovan and Frank Pasmans for the use of their images. We would also like to thank the anonymous reviews, Rachel Antwis and John C. George for comments on an earlier version of the manuscript. Their comments greatly improved the quality of the document.

This work was supported by the Natural Environment Research Council through the EnvEast Doctoral Training Partnership [grant number NE/L002582/1] to S.J.R.A.

\section{REFERENCES}

Acevedo-Whitehouse, K. \& Duffus, A. L .J. (2009). Effects of environmental change on wildlife health. Philosophical Transactions of the Royal Society B 364, 3429-3438.

Adams, M. J., Galvan, S., Scalera, R., Grieco, C. \& Sindaco, R. (2008). Batrachochytrium dendrobatidis in amphibian populations in Italy. Herpetological Review 39, 324-326.

Alves de Matos, A.A., Caeiro, M.F., Marschang, R.E., Papp, T., Soares, C., Marçal, M.R. \& Carretero, M.A. (2008). Adaptation of ranaviruses from Peneda-Gerês National Park (Portugal) 
to cell cultures and their characterization. Microscopy and Microanalysis 14, 139-140.

Ariel, E., Kielgast, J., Svart, H.E., Larsen, K., Tapiovaara, H., Jensen, B. B. \& Holopainen, R. (2009). Ranavirus in wild edible frogs Pelophylax kl. esculentus in Denmark. Diseases of Aquatic Organisms 85, 7-14.

Azmanis, P. N., Strachinis, I., Lymberakis, P. \& Marschang, R. E. (2016). First detection of the amphibian chytrid fungus (Batrachochytridium dendrobatidis) in free-living anuran populations in Greece. Journal of the Hellenic Veterinary Medical Society 67, 253-258.

Baláž, V., Vojar, J., Civi, P. \& Rozínek, R. (2014). Chytridiomycosis risk among Central European amphibians based on surveillance data. Diseases of Aquatic Organisms 112, 1-8.

Baláz, V., Solský, M., Lastra González, D., Havlıková, B., Gallego Zamorano, J., González Sevilleja, C., Torrent, L. \& Vojar, J. (2018). First survey of pathogenic fungus Batrachochytrium salamandrivorans in wild and captive amphibians in the Czech Republic. Salamandra 54, 87-91.

Balseiro, A., Dalton, K. P., del Cerro, A., Marquez, I., Cunningham, A. A., Parra, F., Prieto, J.M. \& Casais, R. (2009). Pathology, isolation and characterization of a Ranavirus from the common midwife toad, Alytes obstetricans, on the Iberian Peninsula. Diseases of Aquatic Organisms 8, 950-954.

Balseiro, A., Dalton, K. P., del Cerro, A., Marquez, I., Parra, F., Prieto, J.M. \& Casais. R. (2010). Outbreak of common midwife toad virus in alpine newts (Mesotriton alpestris cyreni) and common midwife toad (Alytes obstetricans) in northern Spain: a comparative pathological study of an emerging Ranavirus. Veterinary Journal 186, 256-258.

Bennati, R., Bonetti, M., Lavazza, A. \& Gemetti, D. (1994). Skin lesions associated with herpesvirus-like particles in frogs (Rana dalmatina). Veterinary Record 135, 625-626.

Berger, L., Speare, R., Daszak, P., Green, D. E., Cunningham, A. A., Goggin, C. L., Slocombe, R., Ragan, M. A., Hyatt, A. D., McDonald, K. R., \& Hines, H. B. (1998). Chytridiomycosis causes amphibian mortality associated with population declines in the rain forests of Australia and Central America. Proceedings of the National Academy of Sciences 95, 90319036.

Bielby, J., Bovero, S., Sotgiu, G., Tessa, G., Favelli, M., Angelini, C., Doglio, S., Clare, F. C., Gazzaniga, E., Lapietra, F. \& Garner, T. W. J. (2009). Fatal chytridiomycosis in the Tyrrhenian painted frog. EcoHealth 6, 27-32.

Bielby, J., Fisher, M. C., Clare, F. C., Rosa, G.M. \& Garner, T. W .J. (2015). Host species vary in infection probability, sub-lethal effects, and costs of immune response when exposed to an amphibian parasite. Scientific Reports 5, 10828.

Blaustein, A., Urbina, J., Snyder, P. W., Reynolds, E., Dang, T., Hoverman, J. T., Han, B., Olson, D. H., Searle, C. \& Hambalek, N. (2018). Effects of emerging infectious diseases on amphibians: a review of experimental studies. Diversity 10, 81.

Blooi, M., Pasmans, F., Longcore, J. E., Spitzen-Van Der Sluijs, A., Vercammen, F. \& Martel, A. (2013). Duplex real-time PCR for rapid simultaneous detection of Batrachochytrium dendrobatidis and Batrachochytrium salamandrivorans in amphibian samples. Journal of Clinical Microbiology 51, 4173-4177.

Bosch, J., Martínez-Solano, I. \& García-París, M. (2001). Evidence of a chytrid fungus infection involved in the decline of the common midwife toad (Alytes obstetricans) in protected areas of central Spain. Biological Conservation 97, 331-337.

Bosch, J. \& Martínez-Solano, I. (2006). Chytrid fungus infection related to unusual mortalities of Salamandra salamandra and Bufo bufo in the Penalara Natural Park, Spain. Oryx 40, 84-89.

Bosch, J., García-Alonso, D., Fernández-Beaskoetxea, S., Fisher, M. C. \& Garner, T. W. (2013). Evidence for the introduction of lethal chytridiomycosis affecting wild betic midwife toads (Alytes dickhilleni). EcoHealth 10, 82-89.

Bovero, S., Sotgiu, G., Angelini, C., Doglio, S., Gazzaniga, E., Cunningham, A.A. \& Garner, T.W.J. (2008). Detection of chytridiomycosis caused by Batrachochytrium dendrobatidis in the endangered Sardinian newt (Euproctus platycephalus) in southern Sardinia, Italy. Journal of Wildlife Diseases 44, 712-715.

Boyle, D.G., Boyle, D.B., Olsen, V., Morgan, J.A.T. \& Hyatt, A.D. (2004). Rapid quantitative detection of chytridiomycosis (Batrachochytrium dendrobatidis) in amphibian samples using real-time Taqman PCR assay. Diseases of Aquatic Organisms 60, 141-148.

Campbell, L.J., Garner, T.W.J., Tessa, G., Scheele, B.C., Griffiths, A.G.F., Wilfert, L., \& X.A. Harrison (2018). An emerging viral pathogen truncates population age structure in a European amphibian and may reduce population viability. PeerJ 6:e5949 https://doi.org/10.7717/peerj.5949.

Ceballos, G., Ehrlich, P.R., \& Dirzo, R. (2017) Biological annihilation via the ongoing sixth mass extinction signaled by vertebrate population losses and declines. Proceedings of the National Academy of Sciences 114, E6089-E6096.

Chinchar, V.G., Hick, P., Ince, I.A., Jancovich, J.K., Marschang, R., Qin, Q., Subramaniam, K., Waltzek, T.B., Whittington, R., Williams, T., Zhang, Q. \& ICTV Report Consortium. (2017). ICTV Virus Taxonomy Profile: Iridoviridae, Journal of General Virology 98, 890-891.

Civiš, P., Vojar, J., Literák, I. \& Baláž, V. (2012). Current state of $B d$ occurrence in the Czech Republic. Herpetological Review 43, 75-78.

Claytor, S.C., Subramaniam, K., Landrau-Giovannetti, N., Chinchar, V.G., Gray, M.J., Miller, D.L., Mavian, C., Salemi, M., Wisely, S., \& Waltzek, T.B. (2017). Ranavirus phylogenomics: Signatures of recombination and inversions among bullfrog ranaculture isolates. Virology 511, 330-343

Cunningham, A.A., Langton, T.E.S., Bennett, P.M., Drury, S. E. N., Gough, R.E. \& Kirkwood, J.K. (1993). Unusual mortality associated with poxvirus-like particles in frogs (Rana temporaria). Veterinary Record 133, 141-142.

Cunningham, A.A., Langton, T.E.S., Bennett, P.M., Lewin, J.F., Drury, S.E.N., Gough, R.E. \& MacGregor, S.K. (1996). Pathology and microbiological findings from incidents of unusual mortality of the common frog (Rana temporaria). Philosophical Transactions of the Royal Society of London $B$ 351, 1539-1557.

Cunningham, A.A., Hyatt, A.D., Russell, P. \& Bennett, P.M. (2007a). Emerging epidemic diseases of frogs in Britain are dependent on the source of the Ranavirus agent and the route of exposure. Epidemiology and Infections 135, 12001212.

Cunningham, A.A., Hyatt, A.D., Russell, P. \& Bennett, P.M. (2007b). Experimental transmission of a Ranavirus disease of common toads (Bufo bufo) to common frogs (Rana 
temporaria). Epidemiology and Infections 135, 1213-1216.

Cunningham, A.A., Smith, F., McKinley, T.J., Perkins, M.W., Fitzpatrick, L.D., Wright, O.N. \& Lawson, B. (2019). Apparent absence of Batrachochytrium salamandrivorans in wild urodeles in the United Kingdom. Scientific Reports 9, 2831.

Dalbeck, L., Düssel-Siebert, H., Kerres, A., Kirst, K., Koch, A., Lötters, S., Ohlhoff, D., Sabino-Pinto, J., Preißler, K., Schulte U., Schulz, V., Steinfartz, S., Veith, M., Vences, M., Wagner N. \& Wegge, J. (2018). Die Salamanderpest und ihr Erreger Batrachochytrium salamandrivorans (Bsal): aktueller Stand in Deutschland. Zeitschrift für Feldherpetologie 25, 1-22.

Daszak, P., Berger, L., Cunningham, A.A., Hyatt, A.D., Green, D.E. \& Speare, R. (1999). Emerging infectious diseases and amphibian population declines. Emerging Infectious Diseases 5, 735-748.

Daszak, P., Cunningham, A.A. \& Hyatt, A.D. (2000) Emerging infectious diseases of wildlife--threats to biodiversity and human health. Science 287, 443-449.

Daszak, P., Cunningham, A.A. \& Hyatt, A.D. (2003) Infectious disease and amphibian population declines. Diversity and Distributions 9, 141-150.

Daum, J.M., Davis, L.R., Bigler, L. \& Woodhams, D.C. (2012). Hybrid advantage in skin peptide immune defenses of water frogs (Pelophylax esculentus) at risk from emerging pathogens. Infection, Genetics and Evolution 12, 1854-1864.

de Castro, F. \& Bolker, B. (2005) Mechanisms of disease-induced extinction. Ecology Letters 8, 117-126.

DiRenzo, G.V., Campbell Grant, E.H., Longo, A.V., Che-Castaldo, C., Zamudio, K.R. \& Lips, K.R. (2018). Imperfect pathogen detection from non-invasive skin swabs biases disease inference. Methods in Ecology and Evolution 9, 380-389.

Dolinski, A.C., Allender, M.C., Hsiao, V. \& Maddox, C.W. (2014). Systemic Ophidiomyces ophiodiicola infection in a freeranging plains garter snake (Thamnophis radix). Journal of Herpetological Medicine and Surgery 24, 7-10.

Drury, S.E.N., Gough, R.E. \& Cunningham, A.A. (1995). Isolation of an iridovirus-like agent from common frogs (Rana temporaria). Veterinary Record 137, 72-73.

Duffus, A.L.J. \& Cunningham, A.A. (2010). Major disease threats to European amphibians. The Herpetological Journal 20, 117-127.

Duffus, A.L.J., Fenton, H.M.A., Gray, M.J. \& Miller, D.L. (2017). Investigating amphibian and reptile mortalities: A practical guide for wildlife professionals. Herpetological Review 48, 550-557.

Duffus, A.L.J., Garner, T.W.J., Davis, A.R., Dean, A.W. and R.A. Nichols. (2017). Phylogenetic analysis of 24 Ranavirus isolates from English amphibians using 2 partial loci. Journal of Emerging Diseases and Virology 3, 131.

Duffus, A.L.J., Nichols, R.A. \& Garner, T.W.J. (2014). Detection of a Frog Virus 3-like Ranavirus in Native and Introduced Amphibians in the United Kingdom in 2007 and 2008. Herpetological Review 45, 608-610.

Duffus, A.L.J., Waltzek, T.B., Stöhr, A.C., Allender, M.C., Gotesman, M., Whittington, R.J., Hick, P., Hines, M.K. \& Marschang, R.E. (2015). Distribution and host range of ranaviruses. In Ranaviruses, Gray, M.J., \& Chinchar V.G. Eds. Springer.

Farrer, R.A., Weinert, L.A., Bielby, J., Garner, T.W., Balloux, F., Clare, F., Bosch, J., Cunningham, A.A., Weldon, C., du Preez, L.H. \& Anderson, L. (2011). Multiple emergences of genetically diverse amphibian-infecting chytrids include a globalized hypervirulent recombinant lineage. Proceedings of the National Academy of Sciences 108(46), 18732-18736.

Fijan, N., Matašin, Z. Petrinec, Z., Valpotić, I. \& Zwillenberg, L.O. (1991). Isolation of an iridovirus-like agent from the green frog (Rana esculenta L.). Veterinarski Arhiv 61, 151-158.

Fisher, M.C., Bosch, J., Yin, Z., Stead, D.A., Walker, J., Selway, L., Brouwn, A.J.P., Walker, L.A., Gow, N.A.R., Stajich, J.E. \& Garner, T.W.J. (2009). Proteomic and phenotypic profiling of the amphibian pathogen Batrachochytrium dendrobatidis shows that the genotype is linked to virulence. Molecular Ecology 18, 415-429.

Fitzpatrick, L.D., Pasmans, F., Martel, A. \& Cunningham, A. A. (2018). Epidemiological tracing of Batrachochytrium salamandrivorans identifies widespread infection and associated mortalities in private amphibian collections. Scientific Reports 8, 13845.

Franklinos, L.H.V., Lorch, J.M., Bohuski, E., Fernandez, J.R.R., Wright, O.N., Fitzpatrick, L., Petrovan, S., Durrant, C., Linton, C., Baláž, V. \& Cunningham, A.A. (2017). Emerging fungal pathogen Ophidiomyces ophiodiicola in wild European snakes. Scientific Reports 7, 3844.

Franklinos, L.H.V., Rodrigues-Ramos Fernandes, J., Hydeskov, H.B., Hopkins, K.P., Everest, D.J., Cunningham, A.A. \& Lawson, B. (2018). Herpesvirus skin disease in free-living common frogs Rana temporaria in Great Britain. Diseases of Aquatic Organisms 129, 239-244.

Garner, T. W.J., Walker, S., Bosch, J., Hyatt, A.D., Cunningham, A.A. \& Fisher, M.C. (2005). Chytrid fungus in Europe. Emerging Infectious Diseases 11, 1639-1641.

Garner, T.W.J., Perkins, M.W., Govindarajulu, P., Seglie, D., Walker, S., Cunningham, A.A. \& Fisher, M.C. (2006). The emerging amphibian pathogen Batrachochytrium dendrobatidis globally infects introduced populations of the North American bullfrog, Rana catesbeiana. Biology Letters 2, 455-459.

Garner, T.W.J., Garcia, G., Carroll, B. \& Fisher, M.C. (2009b). Using itraconazole to clear Batrachochytrium dendrobatidis infection, and subsequent depigmentation of Alytes muletensis tadpoles. Diseases of Aquatic Organisms 83, 257-260.

Garner, T.W.J., Walker, S., Bosch, J., Leech, S., Rowcliffe, J.M., Cunningham, A.A. \& Fisher, M.C. (2009a). Life history tradeoffs influence mortality associated with the amphibian pathogen Batrachochytrium dendrobatidis. Oikos 118, 783791.

Garner, T.W.J., Martel, A., Bielby, J., Bosch, J., Anderson, L.G., Meredith, A., Cunningham, A.A., Fisher M.C., Henk, D.A. \& Pasmans, F. (2013). Infectious diseases that may threaten Europe's amphibians. In: Amphibian Biology Volume 11: Status of Conservation and Decline of Amphibians: Eastern hemisphere, Part 3: Western Europe. Eds: Heatwole, H. \& Wilkinson, J.W., Pelagic Publishing, Exeter, United Kingdom.

Gibbons, J.W., Scott, D.E., Ryan, T.J., Buhlmann, K.A., Tuberville, T.D., Metts, B.S., Greene, J.L., Mills, T., Leiden, Y., Poppy, S. \& Winne, C.T. (2000). The global decline of reptiles, Déjà Vu Amphibians: reptile species are declining on a global scale. Six significant threats to reptile populations are habitat loss and degradation, introduced invasive species, environmental pollution, disease, unsustainable use, and global climate change. AIBS Bulletin 50, 653-666.

González, D. L., Baláž, V., Solský, M., Thumsová, B., Kolenda, 
K., Najbar, A., Kautman, M., Chajma, R., Balogová, M. \& Vojar, J. (2019). Recent findings of potentially lethal salamander fungus Batrachochytrium salamandrivorans. Emerging Infectious Diseases 25(7), 1416-1418.

Grasselli, E., Bianchi, G., Dondero, L., Marchianò, V., Carafa, M., Perrone, M. \& Salvidio, S. (2019). First screening for Batrachochytrium salamandrivorans (Bsal) in wild and captive salamanders from Italy. Salamandra 5(2), 124-126.

Gray, M.J., Duffus, A.L.J., Haman, K.H., Harris, R.N., Allender, M.C., Thompson, T.A., Christman, M.R., Sacerdote-Velat, A., Sprague, L.A., Williams, J.M. \& Miller, D.L. (2017). Pathogen Surveillance in Herpetofaunal Populations: Guidance on Study Design, Sample Collection, Biosecurity, and Intervention Strategies. Herpetological Review 48, 334-351.

Grogan, L.F., Robert, J., Berger, L., Skerratt, L.F., Scheele, B.C., Castley, J.G., Newell, D.A. \& McCallum, H. I. (2018). Review of the Amphibian Immune Response to Chytridiomycosis, and Future Directions. Frontiers in Immunology 9, 2536.

Hidalgo-Vila, J., Díaz-Paniagua, C., Marchand, M.A. \& Cunningham, A.A. (2012). Batrachochytrium dendrobatidis infection of amphibians in the Doñana National Park, Spain. Diseases of Aquatic Organisms 98, 113-119.

Holopainen, R., Ohlemeyer, S., Schütze, H., Bergmann, S.M. \& Tapiovaara, H. (2009). Ranavirus phylogeny and differentiation based on major capsid protein, DNA polymerase and neurofilament triplet $\mathrm{H} 1$-like protein genes. Diseases of Aquatic Organisms 85, 81-91.

Hyatt, A.D., Gould, A.R., Zupanovic, Z., Cunningham, A.A., Henstberger, S., Whittington, R.J., Kattenbelt, J. \& Coupar, B.E.H. (2000). Comparative studies of piscine and amphibian iridoviruses. Archives of Virology 145, 301-331.

Jakob-Hoff R.M., MacDiarmid S.C., Lees C., Miller P.S., Travis D. \& Kock R. (2014). - Manual of Procedures for Wildlife Disease Risk Analysis. World Organisation for Animal Health, Paris, 160 pp. Published in association with the International Union for Conservation of Nature and the Species Survival Commission.

Kärvemo, S., Meurling, S., Berger, D., Höglund, J. \& Laurila, A. (2018). Effects of host species and environmental factors on the prevalence of Batrachochytrium dendrobatidis in northern Europe. PLoS ONE 13, e0199852.

Kik, M., Martel, A., Spitzen-van der Sluijs, A., Pasmans, F., Wohlsein, P., Gröne, A. \& Rijks, J.M. (2011). Ranavirusassociated mass mortality in wild amphibians, The Netherlands, 2010: A first report. The Veterinary Journal 190, 284-286.

Kolenda, K., Najbar, A., Ogielska, M. \& Balá, V. (2017). Batrachochytrium dendrobatidis is present in Poland and associated with reduced fitness in wild populations of Pelophylax lessonae. Diseases of Aquatic Organisms 124, 241-245.

Laking, A.E., Ngo, H.N., Pasmans, F., Martel, A. \& Nguyen, T.T. (2017). Batrachochytrium salamandrivorans is the predominant chytrid fungus in Vietnamese salamanders. Scientific Reports 7, 44443

Langwig, K.E., Voyles, J., Wilber, M.Q., Frick, W.F., Murray, K.A., Bolker, B.M., Collins, J.P., Cheng, T.L., Fisher, M.C., Hoyt, J.R. et al. (2015). Context-dependent conservation responses to emerging wildlife diseases. Frontiers in Ecology and the Environment 13, 195-202.

Lorch, J. M., Lankton, J., Werner, K., Falendysz, E. A., McCurley ,
K. \& Blehert, D. S. (2015). Experimental infection of snakes with Ophidiomyces ophiodiicola causes pathological changes that typify snake fungal disease. mBio 6, e01534-15.

Lorch, J. M., Knowles, S., Lankton, J. S., Michell, K., Edwards, J.L., Kapfer, J. M., Staffen, R. A., Wild, E.R., Schmidt, K.Z., Ballmann, A. E., \& Blodgett, D. (2016). Snake fungal disease: an emerging threat to wild snakes. Philosophical Transactions of the Royal Society B 371, e20150457.

Madsen, T., Stille, B. \& Shine, R. (1996). Inbreeding depression in an isolated population of adders Vipera berus. Biological Conservation 75, 113-118.

Mali, I., Villamizar-Gomez, A., Krizmanić, I., Ajtić, R. \& Forstner, M.R. (2017). Evidence of Batrachochytrium dendrobatidis Infection in Amphibians from Serbian Lowlands. Journal of Wildlife Diseases 53, 686-689.

Marantelli, G., Berger, L., Speare, R. \& Keegan, L. (2004). Distribution of the amphibian chytrid Batrachochytrium dendrobatidis and keratin during tadpole development. Pacific Conservation Biology 10, 173-179.

Marschang, R.E. (2011). Viruses infecting reptiles. Viruses 3, 2087-2126.

Martel, A., Fard, M.S., Van Rooij, P., Jooris, R., Boone, F., Haesebrouck, F., Van Rooij, D. \& Pasmans, F. (2012). Roadkilled common toads (Bufo bufo) in Flanders (Belgium) reveal low prevalence of ranaviruses and Batrachochytrium dendrobatidis. Journal of Wildlife Diseases 48, 835-839.

Martel, A., Spitzen-van der Sluijs, A., Blooi, M., Bert, W., Ducatelle, R., Fisher, M.C., Woeltjes, A., Bosman, W., Chiers, K., Bossuyt, F. \& Pasmans, F. (2013). Batrachochytrium salamandrivorans sp. nov. causes lethal chytridiomycosis in amphibians. Proceedings of the National Academy of Sciences, 201307356.

Martel, A., Blooi, M., Adriaensen, C., Van Rooij, P., Beukema, W., Fisher, M.C., Farrer, R.A., Schmidt, B.R., Tobler, U., Goka, K., Lips, K.R., Muletz, C., Zamudio, K.R., Bosch, J. Lötters, S., Wombwell, E., Garner, T.W. J., Cunningham, A.A., Spitzenvan der Sluijs, A., Salvidio, S., Ducatelle, R., Nishikawa, K., Nguyen, T.T., Kolby, J.E., Van Bocxlaer, I., Bossuyt, F. \& Pasmans, F. (2014). Recent introduction of a chytrid fungus endangers Western Palearctic salamanders. Science 346, 630-631.

Martínez-Solano, I., Bosch, J., \& García-París, M. (2003). Demographic trends and community stability in a montane amphibian assemblage. Conservation Biology 17, 238-244.

Miaud, C., Pozet, F., Gaudin, N.C.G., Martel, A., Pasmans, F. \& Labrut, S. (2016). Ranavirus causes mass die-offs of alpine amphibians in the southwestern Alps, France. Journal of Wildlife Diseases 52, 242-252.

Meier, G., Notomista, T., Marini, D. \& Ferri, V. (2018). First case of Snake Fungal Disease affecting a free-ranging Natrix natrix (Linnaeus, 1758) in Ticino Canton, Switzerland. Herpetology Notes 11, 885-891.

Mutchmann, F. \& Scheenweiss, D. (2008). Herpes virus infektionen bei Pelobates fuscus und anderen anuren in Berlin-Brandenburg Raum. Rana Sonderheft 5, 113-118.

Nazir, J., Spengler, M. \& Marschang, R. E., 2012. Environmental persistence of amphibian and reptilian ranaviruses. Diseases of Aquatic Organisms 98, 177-184.

Nguyen, T.T., Van Nguyen, T., Ziegler, T., Pasmans, F. \& Martel, A. (2017). Trade in wild anurans vectors the urodelan pathogen Batrachochytrium salamandrivorans into Europe. 
Amphibia-Reptilia 38, 554-556.

Nichols, D. K., Lamirande, E. W., Pessier, A. P. \& Longcore, J. E. (2001). Experimental transmission of cutaneous chytridiomycosis in dendrobatid frogs. Journal of Wildlife Diseases 37, 1-11.

O'Hanlon, S. J., Rieux, A, Farrer, R.A., Rosa, G.M., Waldman, B., Bataille, A., Kosch, T.A., Murray, K.A., Brankovics, B., Fumagalli, M., Martin, M.D., Wales, N., Alvarado-Rybak, M., Bates, K.A., Berger, L. et al. (2018). Recent Asian origin of chytrid fungi causing global amphibian declines. Science 360, 621-627.

Ohst, T., Gräser, Y., Mutschmann, F. \& Plötner, J. (2011). Neue Erkenntnisse zur Gefährdung europäischer Amphibien durch den Hautpilz Batrachochytrium dendrobatidis. Zeitschrift für Feldherpetologie 18, 1-17.

Ohst, T., Gräser, Y. \& Plötner, J. (2013). Batrachochytrium dendrobatidis in Germany: distribution, prevalences, and prediction of high risk areas. Diseases of Aquatic Organisms 107, 49-59.

Olson, D.H., Aanensen, D.M., Ronnenberg, K.L., Powell, C.I., Walker, S.F., Bielby, J., Garner, T.W.J., Weaver, G. \& Fisher, M.C., (2013). Mapping the global emergence of Batrachochytrium dendrobatidis, the amphibian chytrid fungus. PLOS ONE 8 , e56802.

Origgi, F.C., Schmit, B.R., Lohman, P., Otten, P., Akdesir, A., Gashen, V., Aguilar-Bultet, L., Wahli, T., Sattler, U. \& Stoffel, M.H. (2017). Ranid herpesvirus 3 and proliferative dermatitis in free-ranging wild common frogs (Rana temporaria). Veterinary Pathology 54, 686-694.

Origgi, F.C., Schmit, B.R., Lohman, P., Otten, P., Meier, R.K., Pisano, S. R. R., Moore-Jones, G., Tecilla, M., Sattler, U., Wahli, T., Gashen, V. \& Stoffel, M.H. (2018). Bufonid herpesvirus 1 (BfHV1) associated dermatitis and mortality in free ranging common toads (Bufo bufo) in Swizerland. Scientific Reports 8, 14737.

Ouellet, M., Dejean, T. \& Galois, P. (2012). Occurrence of the amphibian chytrid fungus Batrachochytrium dendrobatidis in introduced and native species from two regions of France. Amphibia-Reptilia 33, 415-422.

Paré, J. A. \& Sigler, L. (2016). An overview of reptile fungal pathogens in the genera Nannizziopsis, Paranannizziopsis, and Ophidiomyces. Journal of Herpetological Medicine and Surgery 26, 46-53.

Pasmans, F., Mutschmann, F., Halliday, T. \& Zwart, F. (2006). Amphibian declines: the urgent need for amphibian research in Europe. Veterinary Journal 171, 18-19.

Pasmans, F., Muijsers, M., Maes, S., Van Rooij, P., Brutyn, M., Ducatelle, R., Haesebrouck, F. \& Martel, A. (2010). Chytridiomycosis related mortality in a midwife toad (Alytes obstetricans) in Belgium. Vlaams Diergeneeskundig Tijdschrift 79, 460-462.

Pasmans, F., Van Rooij, P., Blooi, M., Tessa, G., Bogaerts, S., Sotgiu, G., Trenton Garner, T.W.J., Fisher, M.C., Schmidt, B.R., Woeltjes, T. et al. (2013). Resistance to chytridiomycosis in European plethodontid salamanders of the genus Speleomantes. PLOS ONE 8, e63639.

Patrelle, C., Miaud, C., Cristina, N., Kulberg, P. \& Merilä, J. (2012). Chytrid Fungus Screening in a Population of Common Frogs from Northern Finland. Herpetological Review 43, 422-425

Price, S.J., Garner, T.W.J., Nichols, R.A., Balloux, F., Ayres, C., de Alba, A.M.C. \& Bosch, J. (2014). Collapse of amphibian communities due to an introduced Ranavirus. Current Biology 24, 2586-2591.

Price, S.J., Wadia, A., Wright, O.N., Leung, W.T., Cunningham, A.A. \& Lawson, B. (2017). Screening of a long-term sample set reveals two Ranavirus lineages in British herpetofauna. PLOS ONE 12, e0184768.

Rajeev, S., Sutton, D.A., Wickes, B.L., Miller, D.L., Giri, D., Van Meter, M., Thompson, E.H., Rinaldi, M.G., Romanelli, A.M., Cano, J.F. \& Guarro, J. (2009). Isolation and characterization of a new fungal species, Chrysosporium ophiodiicola, from a mycotic granuloma of a black rat snake (Elaphe obsoleta obsoleta). Journal of Clinical Microbiology 47, 1264-1268.

Rijks, J.M., Saucedo, B., Spitzen-van der Sluijs, A., Wilkie, G.S., van Asten, A.J., van den Broek, J., Boonyarittichaikij, R., Stege, M., van der Sterren, F., Martel, A. \& Pasmans, F. (2016). Investigation of amphibian mortality events in wildlife reveals an on-going ranavirus epidemic in the north of the Netherlands. PLoS One 11(6), p.e0157473.

Rosa, G.M., Anza, I., Moreira, P.L., Conde, J., Martins, F., Fisher, M.C. \& Bosch, J. (2013). Evidence of chytrid-mediated population declines in common midwife toad in Serra da Estrela, Portugal. Animal Conservation 16, 306-315.

Rosa, G.M., Sabino-Pinto, J., Laurentino, T.G., Martel, A., Pasmans, F., Rebelo, R., Griffiths, R.A., Stöhr, A.C., Marschang, R.E., Price, S.J. \& Garner, T.W.J. (2017). Impact of asynchronous emergence of two lethal pathogens on amphibian assemblages. Scientific Reports 7, 43260.

Sabino-Pinto, J., Bletz, M., Hendrix, R., Perl, R.B., Martel, A., Pasmans, F., Lötters, S., Mutschmann, F., Schmeller, D.S., Schmidt, B.R. et al. (2015). First detection of the emerging fungal pathogen Batrachochytrium salamandrivorans in Germany. Amphibia-Reptilia 36, 411-416.

Sabino-Pinto, J., Krause, E.T., Bletz, M.C., Martel, A., Pasmans, F., Steinfartz, S. \& Vences, M. (2018). Detectability vs. time and costs in pooled DNA extraction of cutaneous swabs: a study on the amphibian chytrid fungi. Amphibia-Reptilia 40, 29-39 https://doi.org/10.1163/15685381-20181011.

Saucedo, B., Hughes, J., Spitzen-Van Der Sluijs, A., Kruithof, N., Schills, M., Rijks, J.M., Jacinto-Maldonado, M., Suarez, N., Haenen, O.L., Voorbergen-Laarman, M. \& Van Den Broek, J. (2018). Ranavirus genotypes in the Netherlands and their potential association with virulence in water frogs (Pelophylax spp.). Emerging Microbes \& Infections 7, 1-14.

Saucedo, B., Garner, T. W. J., Kruithof, N., Allain, S.J.R., Goodman, M.J., Cranfield, R J., Sergeant, C., Vergara, D.A., Kik, M.J.L., Forzán, M.J., van Beurden, S.J. \& Gröne, A. (2019). Common midwife toad ranaviruses replicate first in the oral cavity of smooth newts (Lissotriton vulgaris) and show distinct strainassociated pathogenicity. Scientific Reports 9, 4453.

Scalera, R., Adams, M.J. \& Galvan, S.K. (2008). Occurrence of Batrachochytrium dendrobatidis in amphibian populations in Denmark. Herpetological Review 39, 199-200.

Scheele, B.C., Pasmans, F., Skerratt, L.F., Berger, L., Martel, A., Beukema, W., Acevedo, A.A., Burrowes, P.A., Carvalho, T., Catenazzi, A. et al. (2019). Amphibian fungal panzootic causes catastrophic and ongoing loss of biodiversity. Science 363:1459-1463.

Scott, M.E. (1988). The impact of infection and disease on animal populations: implications for conservation biology. Conservation Biology 2, 40-56.

Sharifian-Fard, M., Pasmans, F., Adriaensen, C., Devisscher, S., 
Adriaens, T., Louette, G. \& Martel, A., (2011). Ranavirosis in invasive bullfrogs, Belgium. Emerging Infectious Diseases 17, 2371-2372.

Sigler, L., Hambleton, S. \& Paré, J. A. (2013). Molecular characterization of reptile pathogens currently known as members of the Chrysosporium anamorph of Nannizziopsis vriesii (CANV) complex and relationship with some humanassociated isolates. Journal of Clinical Microbiology 51, 3338-3357.

Simoncelli, F., Fagotti, A., Dall'Olio, R., Vagnetti, D., Pascolini, R. \& Di Rosa, I. (2005). Evidence of Batrachochytrium dendrobatidis infection in water frogs of the Rana esculenta complex in central Italy. EcoHealth 2, 307.

Skerratt, L.F., Berger, L., Speare, R., Cashins, S., McDonald, K.R., Phillott, A.D., Hines, H.B. \& Kenyon, N. (2007). Spread of chytridiomycosis has caused the rapid global decline and extinction of frogs. EcoHealth 4, 125-134.

Sodhi, N.S., Bickford, D., Diesmos, A.C., Lee, T.M., Koh, L.P., Brook, B.W., Sekercioglu, C.H. \& Bradshaw, C.J. (2008). Measuring the meltdown: drivers of global amphibian extinction and decline. PLoS one 3, e1636.

Spitzen-van der Sluijs, A., Spikmans, F., Bosman, W., de Zeeuw, M., van der Meij, T., Goverse, E., Kik, M., Pasmans, F. \& Martel, A. (2013). Rapid enigmatic decline drives the fire salamander (Salamandra salamandra) to the edge of extinction in the Netherlands. Amphibia-Reptilia 34, 233239.

Spitzen-van der Sluijs, A., Martel, A., Hallmann, C.A., Bosman, W., Garner, T. W. J., Van Rooij, P., Jooris, R., Haesebrouck, F. \& Pasmans, F. (2014). Environmental determinants of recent endemism of Batrachochytrium dendrobatidis infections in amphibian assemblages in the absence of disease outbreaks. Conservation Biology 28, 1302-1311.

Spitzen-van der Sluijs, A., Martel, A., Asselberghs, J., Bales, E.K., Beukema, W., Bletz, M.C., Dalbeck, L., Goverse, E., Kerres, A., Kinet, T. \& Kirst, K. (2016a). Expanding distribution of lethal amphibian fungus Batrachochytrium salamandrivorans in Europe. Emerging Infectious Diseases 22, 1286.

Spitzen-van der Sluijs, A., van den Broek, J., Kik, M., Martel, A., Janse, J., van Asten, F., Pasmans, F., Gröne, A. \& Rijks, J.M. (2016b). Monitoring Ranavirus-associated mortality in a Dutch heathland in the aftermath of a Ranavirus disease outbreak. Journal of Wildlife Diseases 52, 817-827.

Spitzen-van der Sluijs, A., Pasmans, F., Struijk, R.P., Schils, M., Doornbos, P., van der Sterren, F., Rijks, J., Kik, M., Saucedo, B., Bosman, W. \& Martel, A. (2016c). Course of an isolated Ranavirus outbreak in a Pelobates fuscus population in the Netherlands. Journal of Herpetological Medicine and Surgery 26, 117-121.

Spitzen-van der Sluijs, A., Canessa, S., Martel, A. \& Pasmans, F. (2017). Fragile coexistence of a global chytrid pathogen with amphibian populations is mediated by environment and demography. Proceedings of the Royal Society B: Biological Sciences 284, 20171444.

Spitzen-van der Sluijs, A., Stegen, G., Bogaerts, S., Canessa, S., Steinfartz, S., Janssen, N., Bosman, W., Pasmans, F. \& Martel, A. (2018). Post-epizootic salamander persistence in a disease-free refugium suggests poor dispersal ability of Batrachochytrium salamandrivorans. Scientific Reports 8, 3800.

Stagni, G., Dall'olio, R., Fusini, U., Mazzotti, S., Scoccianti, C. \&
Serra, A. (2004) Declining populations of Apennine yellowbellied toad Bombina pachypus in the northern Apennines (Italy): is Batrachochytrium dendrobatidis the main cause? Italian Journal of Zoology 71, 151-154.

Stegen, G., Pasmans, F., Schmidt, B.R., Rouffaer, L.O., Van Praet, S., Schaub, M., Canessa, S., Laudelout, A., Kinet, T., Adriaensen, C., Haesebrouck, F., Bert, W., Bossuyt, F. \& Martel, A. (2017). Drivers of salamander extirpation mediated by Batrachochytrium salamandrivorans. Nature 544, 353-356.

Stöhr, A.C., Hoffmann, A., Papp, T., Robert, N., Pruvost, N.B., Reyer, H.U. \& Marschang, R.E. (2013). Long-term study of an infection with ranaviruses in a group of edible frogs (Pelophylax kl. esculentus) and partial characterization of two viruses based on four genomic regions. The Veterinary Journal 197, 238-244.

Stöhr, A.C., López-Bueno, A., Blahak, S., Caeiro, M.F., Rosa, G.M., de Matos, A.P.A., Martel, A., Alejo, A. \& Marschang, R.E. (2015). Phylogeny and differentiation of reptilian and amphibian ranaviruses detected in Europe. PLOS ONE 10, e0118633.

Stuart, S.N., Chanson, J.S., Cox, N.A., Young, B.E., Rodrigues, A. S., Fischman, D.L. \& Waller, R.W. (2004). Status and trends of amphibian declines and extinctions worldwide. Science 306, 1783-1786.

Sura, P., Janulis, E. \& Profus, P. (2010). Chytridiomikoza śmiertelne zagrożenie dla płazów. Chrońmy Przyrodę Ojczysta 66, 406-421.

Sztatecsny, M. \& Glaser, F. (2011). From the eastern lowlands to the western mountains: first records of the chytrid fungus Batrachochytrium dendrobatidis in wild amphibian populations from Austria. The Herpetological Journal 21, 8790.

Tan, W.G., Barkman, T.J., Chinchar, V.G. \& Essani, K., (2004). Comparative genomic analyses of frog virus 3 , type species of the genus Ranavirus (family Iridoviridae). Virology 323, 70-84.

Teacher, A.G.F., Cunningham, A.A. \& Garner, T.W.J. (2010). Assessing the long-term impact of Ranavirus infection in wild common frog populations. Animal Conservation 13(5), 514-522.

Thomas, V., Blooi, M., Van Rooij, P., Van Praet, S., Verbrugghe, E., Grasselli, E., Lukac, M., Smith, S., Pasmans, F., and Martel, A., (2018). Recommendations on diagnostic tools for Batrachochytrium salamandrivorans. Transboundary and Emerging Diseases 65, e478-e488.

Tinsley, R.C., Coxhead, P.G., Stott, L.C., Tinsley, M.C., Piccinni, M.Z. \& Guille, M.J. (2015). Chytrid fungus infections in laboratory and introduced Xenopus laevis populations: assessing the risks for UK native amphibians. Biological Conservation 184, 380-388.

Tobler, U. \& Schmidt, B. R. (2010). Within-and among-population variation in chytridiomycosis-induced mortality in the toad Alytes obstetricans. PLoS One 5, e10927.

Tobler, U., Borgula, A. \& Schmidt, B.R. (2012). Populations of a susceptible amphibian species can grow despite the presence of a pathogenic chytrid fungus. PLOS ONE 7, e34667.

Todd, B.D., Willson, J.D. \& Gibbons, J.W. (2010). The global status of reptiles and causes of their decline. In: Ecotoxicology of Amphibians and Reptiles, 2nd Eds: Sparling, D.W., Bishop, 
C.A., \& Krest, S., CRC Press, Boca Raton, USA.

Tünde, G.J., Szabó, K. \& Vörös, J. (2012). Kitridiomikózis vizsgálata egy magas-bakonyi vizes élőhely kétéltűközösségén. Állattani Közlemények 97, 47-59.

Ursenbacher, S., Monney, J.C. \& Fumagalli, L. (2009). Limited genetic diversity and high differentiation among the remnant adder (Vipera berus) populations in the Swiss and French Jura Mountains. Conservation Genetics 10, 303-315.

van Beurden, S.J., Hughes, J., Saucedo, B., Rijks, J., Kik, M., Haenen, O.L., Engelsma, M.Y., Gröne, A., Verheije, M.H., \& Wilkie, G. (2014). Complete genome sequence of a common midwife toad virus-like Ranavirus associated with mass mortalities in wild amphibians in the Netherlands. Genome Announcements 2, e01293-14.

Van Rooij, P., Martel, A., Haesebrouck, F., \& Pasmans, F. (2015). Amphibian chytridiomycosis: a review with focus on fungushost interactions. Veterinary Research 46, 137.

Van Rooij, P., Pasmans, F., Coen, Y. \& Martel, A. (2017). Efficacy of chemical disinfectants for the containment of the salamander chytrid fungus Batrachochytrium salamandrivorans. PLOS ONE 12, e0186269.

Vojar, J., Havlíková, B., Solský, M., Jablonski, D., Iković, V. \& Baláž, V. (2017). Distribution, prevalence and amphibian hosts of Batrachochytrium dendrobatidis in the Balkans. Salamandra 53, 44-49.

Vörös, J., Bosch, J., Dán, Á. \& Hartel, T. (2013). First record of Batrachochytrium dendrobatidis on amphibians in Romania. North-Western Journal of Zoology 9, 446-449.

Wake, D.B. \& Vredenburg, V.T. (2008). Are we in the midst of the sixth mass extinction? A view from the world of amphibians. Proceedings of the National Academy of Sciences 105, 11466-11473.

Weldon, C., Du Preez, L.H., Hyatt, A.D., Muller, R. \& Speare, R. (2004). Origin of the amphibian chytrid fungus. Emerging Infectious Diseases 10, 2100-2105.

Wood, L.R., Griffiths, R.A. \& Schley, L. (2009). Amphibian chytridiomycosis in Luxembourg. Bulletin de la Société des Naturalistes Luxembourgeois 110, 109-114.

Woodhams, D.C., Bigler, L. \& Marschang, R. (2012). Tolerance of fungal infection in European water frogs exposed to Batrachochytrium dendrobatidis after experimental reduction of innate immune defenses. BMC Veterinary Research 8, 197.

World Organisation for Animal Health (OIE) \& International Union for Conservation of Nature (IUCN) (2014). Guidelines for Wildlife Disease Risk Analysis. OIE, Paris, 24 pp. Published in association with the IUCN and the Species Survival Commission.

Zampiglia, M., Canestrelli, D., Chiocchio, A. \& Nascetti, G. (2013). Geographic distribution of the chytrid pathogen Batrachochytrium dendrobatidis among mountain amphibians along the Italian peninsula. Diseases of Aquatic Organisms 107, 61-68.

Accepted: 3 April 2019 